\title{
Post-harvest nitrogen cycling in clearcut and alternative silvicultural systems in a montane forest in coastal British Columbia
}

by Brian D. Titus ${ }^{1,2}$ Cindy E. Prescott ${ }^{3}$, Doug G. Maynard ${ }^{1}$, Alan K. Mitchell ${ }^{1}$, Robert L. Bradley ${ }^{4}$, Michael C. Feller ${ }^{3}$, W.J. (Bill) Beese ${ }^{5}$, Brad A. Seely ${ }^{3}$, Ross A. Benton ${ }^{1}$, John P. Senyk' ${ }^{1}$, Barbara J. Hawkins ${ }^{6}$ and Ross Koppenaal ${ }^{1}$

\section{ABSTRACT}

The MASS (Montane Alternative Silvicultural Systems) trial was established in the coastal mountains of British Columbia to compare clearcut, patch cut, green tree and shelterwood systems. A number of studies were carried out at the MASS trial to determine the extent to which these variable levels of stand retention retained old-growth attributes of $\mathrm{N}$ cycling and associated ecological processes. Harvesting led to increases in $N$ mineralization in the forest floor $(2 \times)$ and mineral soil $(10 \times)$, and fluxes of $\mathrm{N}$ through the upper $25 \mathrm{~cm}$ of mineral soil $(2 \times$ to $3 \times)$. However, fluxes of $\mathrm{N}$ were not large $\left(<0.35 \mathrm{~kg} \mathrm{ha}^{-1}\right.$ per growing season). Nitrogen mineralized was predominantly ammonium and not nitrate in the forest floor (> 95\% in all but clearcut, $>75 \%$ in clearcut) and upper mineral soil horizon (42-86\%). The nitrate component came from heterotrophic decomposition of organic matter, not conversion of ammonium to nitrate by autotrophs, and nitrate increases resulted from decreased gross nitrate consumption with harvesting, rather than increased nitrate production. The increases in soil $\mathrm{N}$ availability resulting from harvesting were reflected in only slight increases in seedling foliar $\mathrm{N}$ concentrations for two to four years after logging (peak of $\sim 2 \%$ for western hemlock and $\sim 1.6 \%$ for amabilis fir) before decreasing to below deficiency thresholds for both species. Overall, estimated losses of $\mathrm{N}$ from the rooting zone after harvesting $\left(1 \mathrm{~kg} \mathrm{ha}^{-1} \mathrm{yr}^{-1}\right)$ were minimal in comparison to estimated $\mathrm{N}$ inputs $\left(4 \mathrm{~kg} \mathrm{ha}^{-1} \mathrm{yr}^{-1}\right), \mathrm{N}$ exports in logs at harvesting $\left(250 \mathrm{~kg} \mathrm{ha}^{-1}\right)$ and soil reserves $\left(11400 \mathrm{~kg} \mathrm{ha}^{-1}\right)$. Although unlikely to affect future site productivity, losses of $\mathrm{N}$ could be reduced somewhat through the use of shelterwood harvesting.

Key words: alternative silvicultural systems, variable retention harvesting, nitrogen cycling, litterfall, decomposition, nitrification, $\mathrm{N}$ mineralization, microbial ecology, leaching, foliar N, Abies amabilis, Tsuga heterophylla, Thuja plicata

\section{RÉSUMÉ}

L'essai MASS (Montane Alternative Silvicultural Systems) a été réalisé dans les montagnes côtières de la ColombieBritannique dans le but de comparer les régimes sylvicoles de coupe à blanc, de coupes par bloc, de rétention d'arbres verts et de coupes progressives. Une série d'études a été réalisée lors de l'essai MASS afin de déterminer jusqu'à quel point ces divers niveaux de rétention du peuplement permettaient de conserver les qualités attribuées aux vieux peuplements au niveau du cycle de l'azote et des processus écologiques associés. La récolte tend accroître la minéralisation de l'azote dans le parterre forestier (2?) et dans le sol minéral (10?) et les fluctuations d'azote dans les $25 \mathrm{~cm}$ supérieurs du sol minéral (de 2? à 3?). Cependant, les fluctuations de l'azote n’étaient pas importantes $\left(<0.35 \mathrm{~kg} \mathrm{ha}^{-1}\right.$ par saison de croissance). L'azote minéralisé était constitué de façon prédominante par de l'ammonium et non des nitrates dans le sol forestier (>95\% dans tous les cas sauf la coupe à blanc, $>75 \%$ dans le cas de la coupe à blanc) et de l'horizon supérieur du sol minéral (42-86\%). La partie nitrate provenait de la décomposition hétérotrophique de la matière organique, non pas de la conversion de l'ammonium en nitrate par autrophie, alors que l'accroissement des nitrates provenait de la diminution de la consommation brute des nitrates par la récolte, plutôt qu'une production accrue de nitrate. Les accroissements de la disponibilité de l'azote dans le sol provenant de la récolte se reflétaient par seulement de faibles accroissements de concentrations d'azote foliaire dans le semis de deux à quatre ans après l'exploitation (un maximum de $\sim 2 \%$ pour la pruche de l'Ouest et de $\sim 1.6 \%$ pour le sapin gracile) avant de décroître sous le seuil de carence pour les deux espèces. Somme toute, les pertes estimées d'azote dans la zone d'enracinement après la récolte $\left(1 \mathrm{~kg} \mathrm{ha}^{-1} \mathrm{an}^{-1}\right)$ étaient minimales en comparaison aux apports estimés d'azote $\left(4 \mathrm{~kg} \mathrm{ha}^{-1} \mathrm{an}^{-1}\right)$, aux pertes d'azote découlant de la récolte des billots $\left(250 \mathrm{~kg} \mathrm{ha}^{-1}\right)$ et des réserves dans le sol (11 $\left.400 \mathrm{~kg} \mathrm{ha}^{-1}\right)$. Même s'il est peu probable qu'elles affectent la productivité future de la station, les pertes d'azote pourraient être réduites d'une certaine façon par l'application de coupes progressives.

Mots clés : régimes sylvicoles alternatifs, récolte avec rétention variable, cycle de l'azote, litière, décomposition, nitrification, N, minéralisation, écologie microbienne, percolation, azote foliaire, Abies amabilis, Tsuga heterophylla, Thuja plicata

\footnotetext{
${ }^{1}$ Natural Resources Canada - Canadian Forest Service, Pacific Forestry Centre, 506 West Burnside Rd., Victoria, British Columbia V8X 1 M5. ${ }^{2}$ Corresponding author: Brian.Titus@NRCan.gc.ca

${ }^{3}$ Dept. of Forest Sciences, University of British Columbia, Forest Sciences Center, 3041 - 2424 Main Mall, Vancouver, British Columbia V6T 1 Z4.

${ }^{4}$ Département de biologie, Université de Sherbrooke, Sherbrooke, Québec J1K 2R1.

${ }^{5}$ Western Forest Products Inc., 118 - 1334 Island Highway, Campbell River, British Columbia V9W 8C9.

${ }^{6}$ Dept. of Biology, University of Victoria, PO Box 3020, Station CSC, Victoria, British Columbia V8W 3N5.
} 


\section{Introduction}

Recent criticism of clearcutting in BC has led to increased use of alternative silvicultural systems for harvesting. These include both traditional silvicultural and variable retention systems (Mitchell and Beese 2002), in which some trees are left across the harvested site as aggregated (e.g., strip cut, patch cut) or dispersed (e.g., shelterwood, green tree) retention. The Montane Alternative Silvicultural Systems (MASS) partnership was formed in 1992 to test several alternative silvicultural systems in an old-growth coastal montane forest on Vancouver Island (Arnott and Beese 1997). The main objectives were to assess the operational costs and feasibility of using shelterwood, green tree retention, patch cut and clearcut systems to harvest an old-growth western hemlockamabilis fir-redcedar (Tsuga heterophylla ((Raf.) Sarg.), Abies amabilis ((Dougl.) Forb.), Thuja plicata (Donn)) forest and to monitor regeneration in each system. Clearcutting in some coastal montane forests in BC can to lead to reduced growth of regeneration (Koppenaal and Mitchell 1992) and this growth check can become apparent at about 12 to 15 years after harvesting. However, it is not known if this results from adverse soil temperature, nutrient availability, plant competition or other processes. The MASS field trial therefore also provided an opportunity to study the effects of silvicultural systems on key ecological processes, especially the causes of seedling growth check. Nitrogen $(\mathrm{N})$ cycling was thus a focus of a number of studies carried out at the MASS site because $\mathrm{N}$ availability often limits tree growth in temperate forest ecosystems, and it is possible that lack of $\mathrm{N}$ availability leads to the growth check observed on these types of sites.

Harvesting affects $\mathrm{N}$ cycling processes (see reviews by Vitousek 1983, Keenan and Kimmins 1993) and the first impact is an immediate reduction in plant uptake of $\mathrm{N}$ as trees are felled (Vitousek and Reiners 1975). Resultant changes in canopy cover can change soil temperature and moisture conditions (McColl 1977, Barg and Edmonds 1999). These abiotic factors in turn affect microbial organisms (Barg and Edmonds 1999, Siira-Pietikäinen et al. 2001) that use the input of slash and roots from dead trees to the forest floor and soil at harvesting as an energy substrate as well as a source of N. Changes in decomposition (Binkley 1984) and nitrification rates can lead to increased nitrate $\left(\mathrm{NO}_{3}-\mathrm{N}\right)$ mobilisation (Vitousek and Melillo 1979, Vitousek 1981). This, along with a reduction in the size of the plant sink, may lead to increased $\mathrm{N}$ movement down the soil profile because nitrate anions are mobile and easily leached. Electrical charges are balanced in the soil solution, and thus the movement of nitrate can cause concomitant movement of mobile cations, including ammonium $\left(\mathrm{NH}_{4}-\mathrm{N}\right)$. The resulting increase in soil $\mathrm{N}$ availability may benefit the growth of seedlings, ground vegetation and remaining trees in what is sometimes called the assart effect (Romell 1957). However, if plant and microbial organisms cannot take up the entire $\mathrm{N}$ available after harvesting then the excess $\mathrm{N}$ can leach below the rooting zone, potentially affecting site productivity and the quality of nearby streams and water bodies (Vitousek et al. 1997). The magnitude and duration of increased $\mathrm{N}$ availability and leaching after harvesting varies, depending on the soil, site and stand type. Changes in $\mathrm{N}$ cycling processes also vary depending on the amount of trees removed and the silvicultural or harvesting system used (Barg and Edmonds 1999, Siira-Pietikäinen et al. 2001).
A range of $\mathrm{N}$ cycling studies has been carried out at the MASS site, predominantly over the first five years after harvesting. The objective of this paper is to up-date some past findings, present new findings, and then synthesize these with previously published work in a review of all the $\mathrm{N}$ cycling work that has been carried out at MASS. The effect of clearcutting will be examined, along with the causes of changes in $\mathrm{N}$ cycling processes. Then the extent to which the variable retention systems applied at MASS mitigate clearcutting effects, especially shelterwood harvesting, will be discussed. Finally, the amount of $\mathrm{N}$ lost and potential effects on future site productivity will be examined in the context of long-term inputs and outputs of $\mathrm{N}$ from the site. Key questions include: (i) what are the effects of clearcutting on $\mathrm{N}$ cycling? (ii) what are the mechanisms that led to the clearcutting effects? (iii) Do alternative silvicultural systems mitigate the effects of clearcutting? and (iv) What is the potential for loss of site productivity after harvesting these sites?

\section{Methods}

Methods are briefly described for studies that have been updated, but full methodologies are given for new work. Only citations are given for previously published work.

\section{Site description}

The MASS site is located near Campbell River, on the east coast of Vancouver Island $\left(49^{\circ} 55^{\prime} \mathrm{N} 125^{\circ} 25 \mathrm{~W}\right)$. The oldgrowth forest ( $>500$ years since last major disturbance) is dominated by 200- to 800 -year-old trees of amabilis fir (Abies amabilis Dougl. ex. Forbes) and western hemlock (Tsuga heterophylla (Raf.) Sarg.), with western redcedar (Thuja plicata Donn ex. D. Don) and yellow-cedar (Chamaecyparis nootkatensis (D. Don) Spach) present in smaller amounts. The site has a slope of $<20 \%$ with a northerly aspect, and is between 740 and $850 \mathrm{~m}$ elevation. Soils are predominantly Orthic and Gleyed Ferro-Humic Podzols, and are typically overlain with a relatively thick $(15-40 \mathrm{~cm})$ mor humus with a large component of decomposed wood in deeper humus layers. Understory vegetation includes Vaccinium alaskaense (Howell), V. ovalifolium (Sm.), Tiarella trifoliata (L.), Streptopus roseus (Michx.), Lysichiton americanum (Hultén \& St. John), Rhytidiadelphus loreus ((Hedw.) Warnstorf), Hylocomium splendens (Hedw.) and Rhytidiopsis robusta ((W.J. Hooker) Brotherus). The site is typical of the montane moist maritime variant of the Coastal Western Hemlock biogeoclimatic zone (CWHmm2). Further site details can be found in Arnott and Beese (1997).

\section{Silvicultural Systems}

Five treatments were compared at MASS (Fig. 1): (i) oldgrowth stand (unharvested control treatment), (ii) clearcut (69 ha; harvested over two years from 1992 to 1993), (iii) shelterwood ( $25 \%$ of original basal area retained; 200 stems ha $^{-1}$ $>17.5 \mathrm{~cm} \mathrm{DBH}$ ), (iv) green tree retention (or clearcutting with reserves; $5 \%$ of original basal area retained; 25 trees ha${ }^{1}$ ), and (iv) patch cut treatment plot (three small cutblocks of 1.5 to 2.0 ha alternating with three leave stands in each plot; unless otherwise stated, results for patch cut treatments are for the cutblocks, not the leave stands in this treatment). The single old-growth stand and clearcut treatments were each divided into three replicates. A nearby area was divided into three blocks, and the three alternative silvicultural treatments 


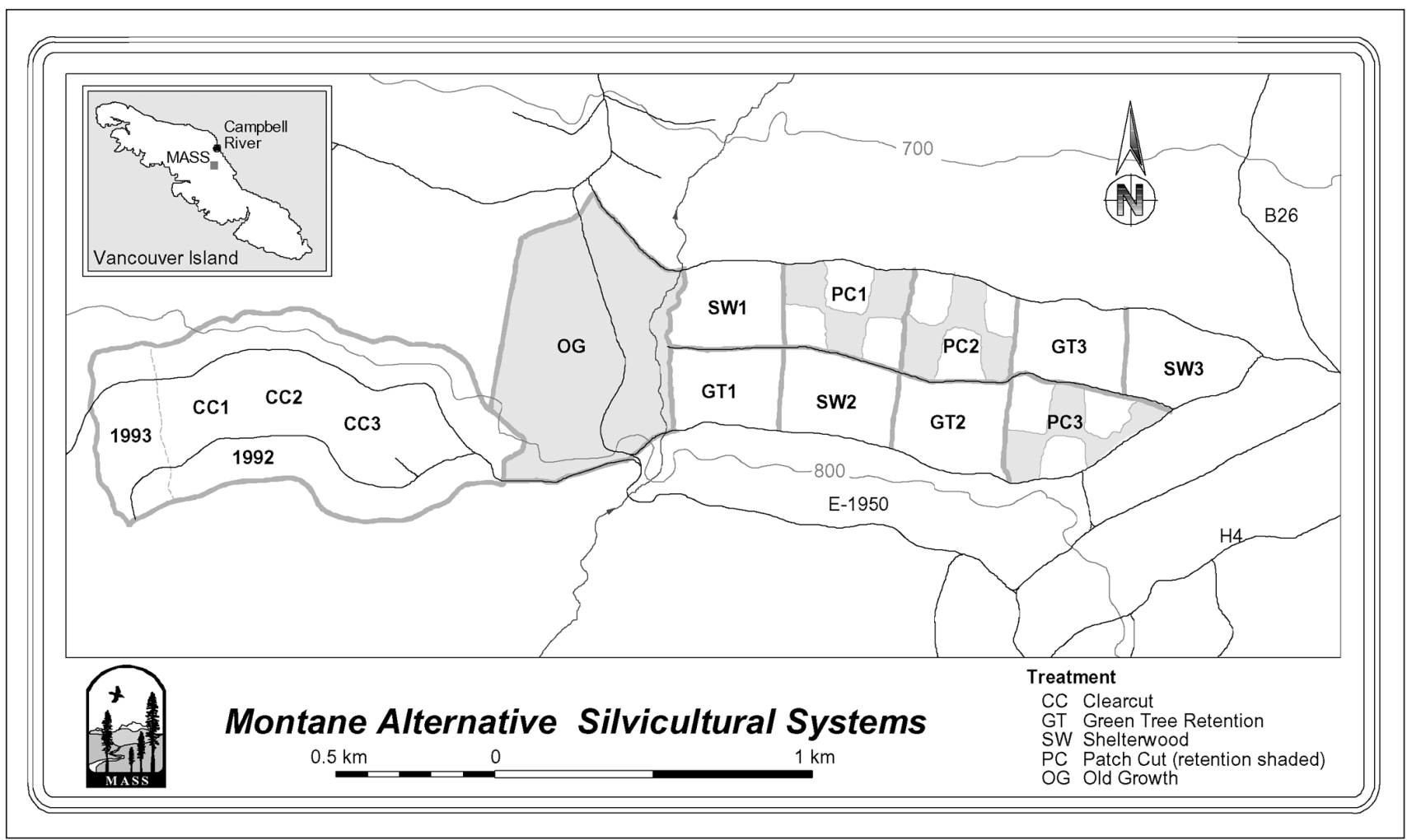

Fig. 1. Layout of silvicultural systems treatments at the MASS site. Number after treatment codes $(O G=$ old-growth, SW = shelterwood, GT = green tree, PC = patch cut, CC = clearcut) identify replicate. Note contiguous clearcut (CC; left of map) and old-growth forest (OG; centre of map) replicates.

were randomly located within each of these, giving three replicates of each treatment. These latter treatments were harvested between May and Nov. 1993, and hence the first full growing season for regeneration was 1994. (See Arnott and Beese (1997) for further site and treatment details.)

\section{Statistical analyses}

Operational constraints precluded unrestricted randomization in both the clearcut and old-growth treatments but, for statistical analyses, it was assumed that variation among replicates in the clearcut and old-growth treatment areas was comparable to variation among the replicates assigned to the alternative silvicultural treatments. One-way ANOVA (assuming the equivalent of a completely randomized design) was therefore used to test for treatment effects, but interpretation of results must be tempered because of the restricted randomization of treatments. Some studies modified this main design, and details for individual studies are therefore given in Table 1. All data passed tests for homogeneity of variance and normality of data, except for litterfall data, which was $\ln$ transformed before analysis. In all figures and tables, means followed by different letters are significantly different at $p<0.05$.

\section{Litterfall}

Three $0.25-\mathrm{m}^{2}$ circular $(56.5-\mathrm{cm}$ diameter) collection bags (after Hughes et al. 1987) were placed $1 \mathrm{~m}$ above the ground in each treatment plot. Litterfall was collected in early spring (May), late summer (Aug.-Sept.) and late fall (Oct.-Nov.) for the first five years after harvesting (1993-98) and oven-dried $\left(80^{\circ} \mathrm{C}\right)$ before weighing.

\section{Litter decomposition}

Mass loss of western hemlock needle litter and forest floor (FH) material was measured using litterbags. Bags were installed in one plot of each treatment immediately after harvesting (Nov. 1993) and were collected annually for the first four years after harvesting. Bags containing needle litter were pinned to the surface of the forest floor, and bags containing FH material were buried in the forest floor. Results for the first two years after harvesting have been published (Prescott 1995, 1997); third- and fourth-year results are included in the current study.

Pairs of birch chopsticks $(20.4 \mathrm{~cm} \times 0.4 \mathrm{~mm} \times 1.2 \mathrm{~cm}$ tapering to $0.7 \mathrm{~mm}$; pre-cut to make a pair, but retained intact) were buried horizontally $\sim 5 \mathrm{~cm}$ below the forest floor surface to obtain a surrogate measurement for decomposition rate in the humus. Four randomly-located points were located in each treatment in one replicate in every May each year for the first three successive years after harvesting (1994-96), using a different replicate each year. Four small quadrats were established within $\sim 1 \mathrm{~m}$ of each point, and then three pre-weighed pairs of chopsticks were buried in each of these four quadrats. Data therefore reflect but cannot distinguish between differences in site and year-to-year climatic conditions. One pair of chopsticks was retrieved from each quadrat after 4, 12 and 16 months (August, May and following August), gently cleaned, oven-dried at $70^{\circ} \mathrm{C}$ for $48 \mathrm{hrs}$ and weighed. The four mass loss values for each sampling station were pooled, to give four values per treatment per replicate. 


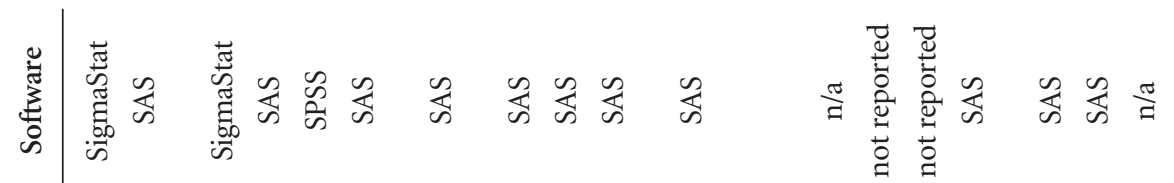

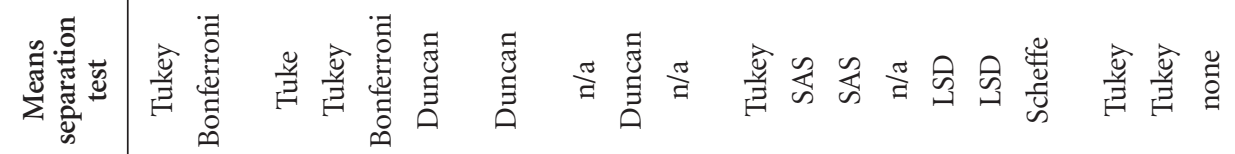

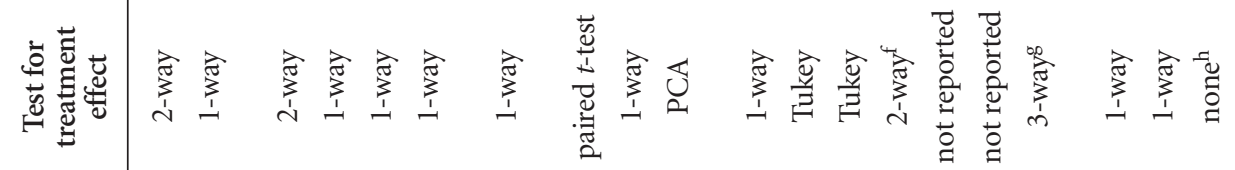

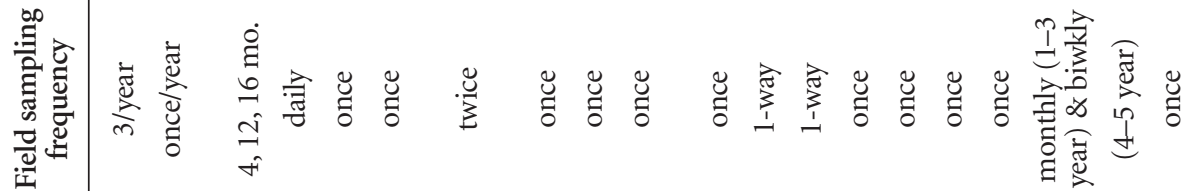

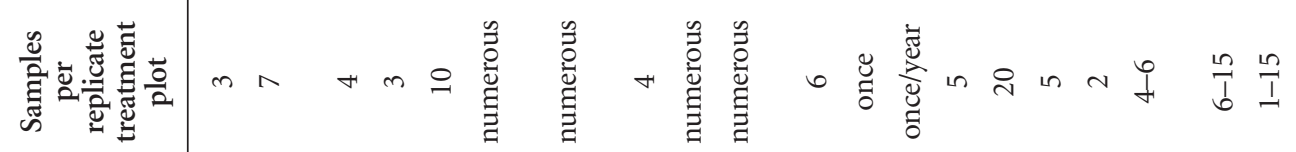

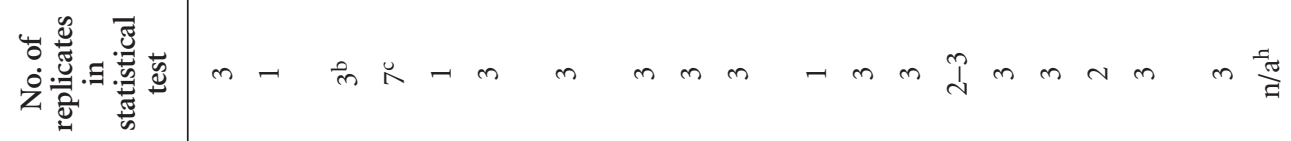

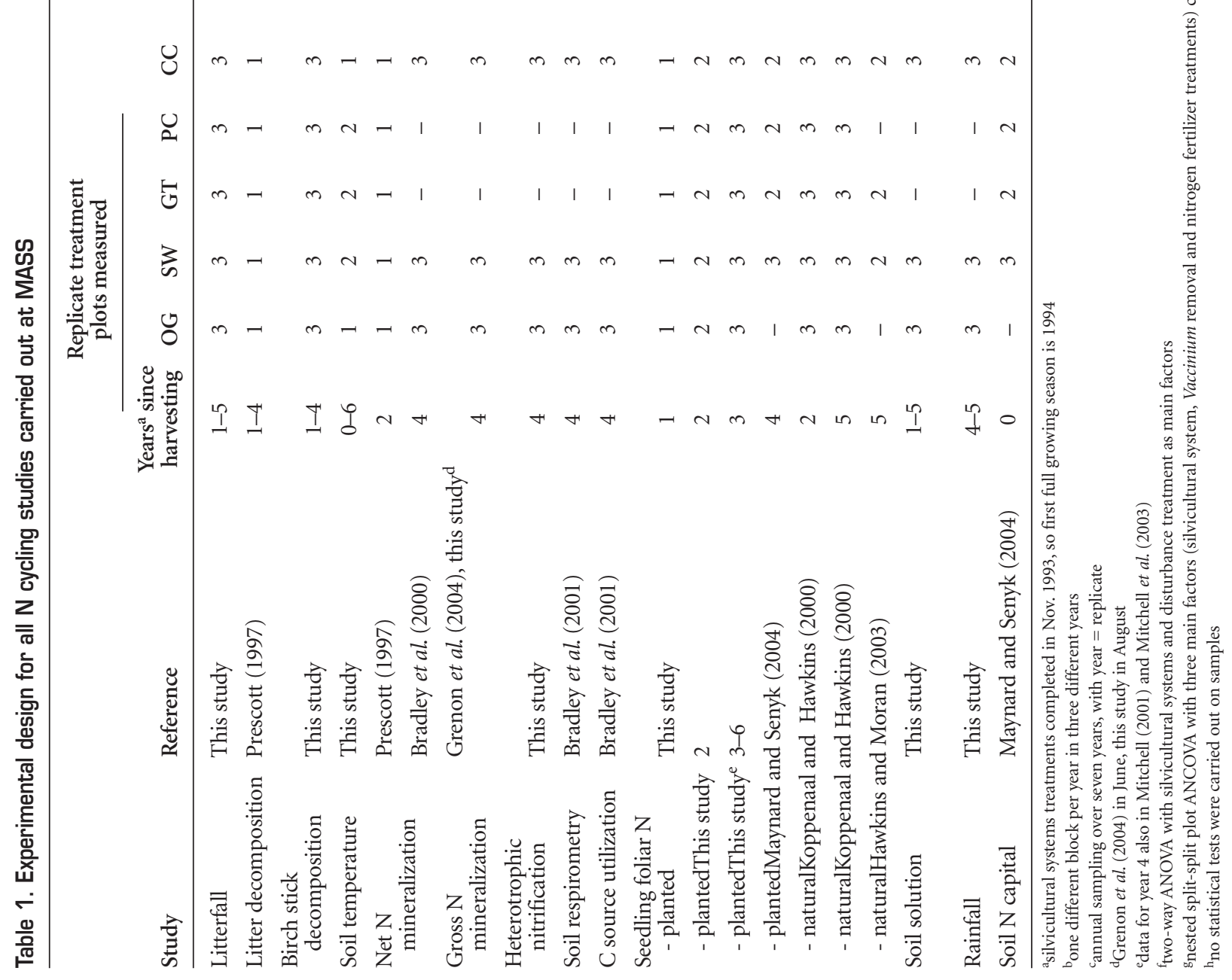




\section{Soil temperature}

Three thermisters (Fenwall UUT51J1) were installed in either two replicates (shelterwood, green tree, patch cut) or one replicate (old-growth, clearcut) of the five treatments (see Dunsworth and Arnott 1995 for initial design) at $5 \mathrm{~cm}$ below the surface of the forest floor, as this is the most relevant depth for decomposition and humus processes. Readings (Campbell Scientific Inc. CR10) were made every minute and integrated hourly and daily over seven years (1993-99). Mean growing degree days $>0,5,7.5$ and $10^{\circ} \mathrm{C}$ (i.e., GDD $=$ accumulated temperature over given temperature threshold for each day of the year) were calculated for each year.

\section{Soil moisture}

Gravimetric water contents of the LF and the $\mathrm{H}$ horizons were determined every two weeks over the fifth growing season after harvesting (1998). Three forest floor samples were collected from three replicates of the old-growth, shelterwood and clearcut treatment plots at the same time that rainfall, throughfall and soil solutions were sampled (see below). Moisture contents (as \% of oven-dry humus mass after $105^{\circ} \mathrm{C}$ for $24 \mathrm{hr}$ ), daily meteorological data from a nearby (Mt. Washington) and an on-site (PC1) climate station, and various vegetation and soil parameters were used as input data for the ForWaDy model (Seely et al. 1997), which was used to predict daily water fluxes through the canopy, forest floor and mineral soil (to $25 \mathrm{~cm}$, corresponding to the middle of the porous cups on lysimeters, and estimated to be the bottom of the rooting zone in which most nutrients would be taken up by trees).

\section{Gross N mineralization}

Gross mineral N transformation rates were measured by isotope dilution (after Hart et al. 1994) on F horizon samples collected from the same plots as in the sampling for net $\mathrm{N}$ mineralization at two different times over the fourth growing season after harvesting (1997) in both June (Grenon et al. 2004) and again in August 1997; see Grenon et al. 2004 for further details on methods).

\section{Heterotrophic nitrification}

Bulked forest floor samples were collected in the fifth growing season after harvesting (August 1998) from the same three replicates of the old-growth, shelterwood and clearcut treatments used for previous studies of net and gross $\mathrm{N}$ mineralization (Bradley et al. 2000, Grenon et al. 2004). Four subsamples from each plot ( $\sim 8 \mathrm{~g}$ dry mass $)$ were placed in jars and injected with $\mathrm{K}^{15} \mathrm{NO}_{3}$ solution. Two of these were immediately injected with acetylene to block autotrophic nitrification. Fifteen minutes after injection, a 2-M KCl solution was added to one jar with and one jar without acetylene addition, and extracts stored at $2^{\circ} \mathrm{C}$. The remaining two jars were sealed, incubated at $22^{\circ} \mathrm{C}$ for $24 \mathrm{hrs}$ and extracted. All extracts were analysed for $\mathrm{NO}_{3}-\mathrm{N}$ concentration. Subsamples of extract were diffused onto acidified glass micro-fibre disks, amended with Devarda's alloy and diffused a second time before being encapsulated in Sn sleeves for analysis for atom $\%{ }^{15} \mathrm{~N}$. Gross production and consumption rates of $\mathrm{NO}_{3}-\mathrm{N}$ were calculated using zero-order equations (Kirkham and Bartholemew 1954).

\section{Seedling foliar $\mathbf{N}$}

Foliage was collected from both planted and naturally-regenerated western hemlock and amabilis fir seedlings in subplots (within the main silvicultural system treatment plots) set up to determine the impacts of competing vegetation and nutrient availability ( \pm herbicide $\times \pm$ fertilizer treatments) on seedling growth (Mitchell and Arnott 1995; Mitchell 2001; Mitchell et al. 2003, 2004). Nitrogen concentrations in current foliage were determined throughout the growing season, but only fall data from control treatments in these sub-plots (i.e., no herbicide, no fertilizer) are presented. Sampling intensity varied between years (Table 1). See Mitchell (2001) and Mitchell et al. (2003) for further details on foliar sampling and analytical methods.

\section{Soil solution}

Porous cup tension lysimeters (SME Model 1900, B2M2 ceramic; $50 \mathrm{kPa}$ tension) were used to sample the soil solution $\sim 25 \mathrm{~cm}$ beneath the surface of the mineral soil (i.e., bottom of cups at $\sim 30 \mathrm{~cm})$. Lysimeters were installed immediately after harvesting (July-August 1993, except for those in the SW plots, which were installed in May 1994). Leachate was collected approximately monthly throughout the growing seasons (May-Oct.) of the first three years after harvesting (1994-96) and every two weeks (June-Sept.) over the fourth and fifth growing seasons (1997-98). (See Feller and Olanski (1995) and Feller et al. (2000) for more details on lysimeters and their installation.)

A subset of the lysimeters used by Feller and Olanski (1995) that were randomly located 30 and $60 \mathrm{~m}$ from treatment plot boundaries were used in the present study. Three treatments were compared: (i) old-growth (one plot in oldgrowth + two leave stands in patch cut; six sampling locations per plot), (ii) clearcut (one plot in clearcut + two cutblocks in patch cut; six sampling locations per plot), and (iii) shelterwood (three plots in one shelterwood treatment replicate, 50 $\mathrm{m}$ apart from each other; four sampling stations per plot). (Minimal or lack of difference in seven-year seedling growth response between clearcut and patch cut treatments (Mitchell et al. 2004) suggests comparability between clearcut and cutblocks in the patch cut treatment.)

All samples were returned to the lab on ice and stored at $5^{\circ} \mathrm{C}$ before analysis for $\mathrm{NO}_{3}-\mathrm{N}$ and $\mathrm{NH}_{4}-\mathrm{N}$ by colorimetric methods on an autoanalyser and for total-N by analysis of $\mathrm{NO}_{3}-\mathrm{N}$ after filtering and persulfate digestion (D'Elia et al. 1977). Samples collected in 1994-96 were individually analysed, and those collected in 1997-98 were bulked by treatment plot before analysis and were not filtered before persulfate digestion. Dissolved organic N (DON) was assumed to be the difference between total- $\mathrm{N}$ and dissolved inorganic $\mathrm{N}\left(\mathrm{DIN}=\mathrm{NO}_{3}-\mathrm{N}+\mathrm{NH}_{4}-\mathrm{N}\right)$.

Chemical concentrations were multiplied by modelled (ForWaDy) water flux rates to give $\mathrm{N}$ fluxes from the bottom of the rooting zone ( $25 \mathrm{~cm}$ below surface of mineral soil). Accumulated $\mathrm{N}$ fluxes over each growing season were calculated for individual lysimeters for the first three growing seasons (1994 to 1996), and means calculated for each replicate of each treatment; samples were bulked by treatment and replicate before chemical analysis for the fourth and fifth seasons (1997 and 1998). The length of the sampling period varied between years, and therefore only fluxes over a standard sampling period were compared. 


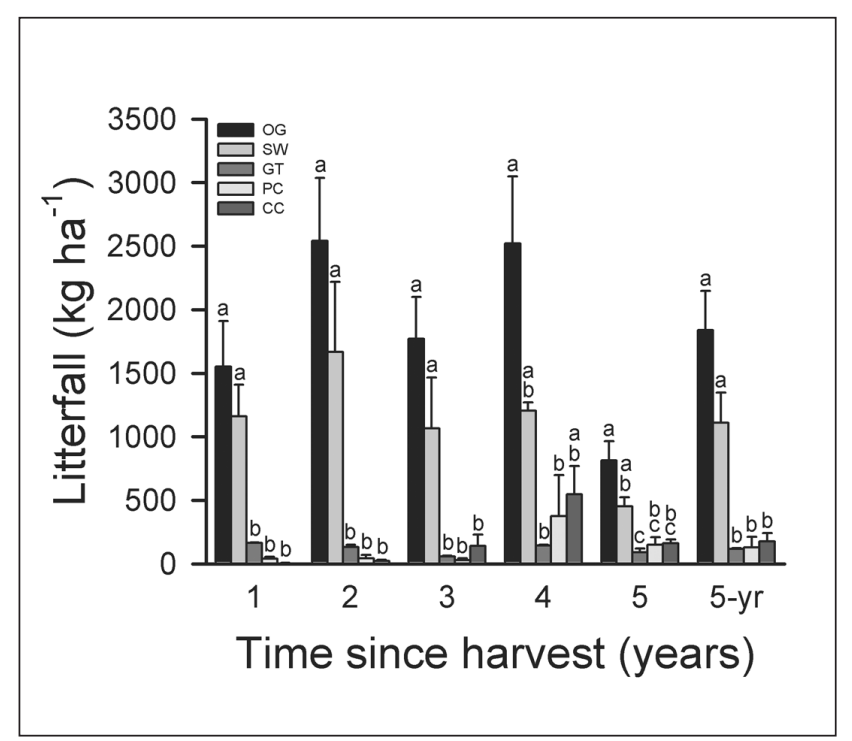

Fig. 2. Mean annual litterfall $( \pm S E)$ during the first five years after harvest (1994-1998) and 5-year average annual litterfall in five different treatments at MASS $1 O G=$ old-growth, SW = shelterwood, GT = green tree, $\mathrm{PC}=$ patch cut, $\mathrm{CC}=$ clearcut; within a given year, means with same letters are not significantly different).

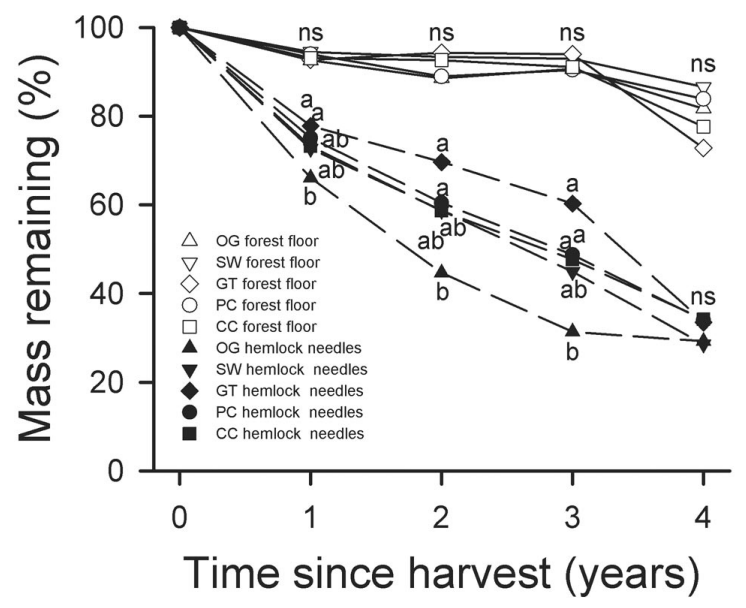

Fig. 3. Mean mass loss from hemlock needle litter and forest floor material incubated in old-growth, shelterwood and clearcut treatment plots over the first four years after harvesting (1993-1997; Prescott 1997 and unpublished data] at MASS IOG = old-growth, SW = shelterwood, GT = green tree, $\mathrm{PC}=$ patch cut, $\mathrm{CC}$ = clearcut; within a given year, means with same letters are not significantly different].

\section{Atmospheric deposition}

Rainfall collectors (14.5- $\mathrm{cm}$ diameter polyethylene funnel with small-mesh screen mounted $1 \mathrm{~m}$ above soil surface on wooden post, draining through Tygon ${ }^{\circledR}$ tubing to 4 -L polyethylene collection vessel) were installed at the beginning of the fourth growing season (June 1997). There were six collectors in each clearcut plot. Collections were made every two

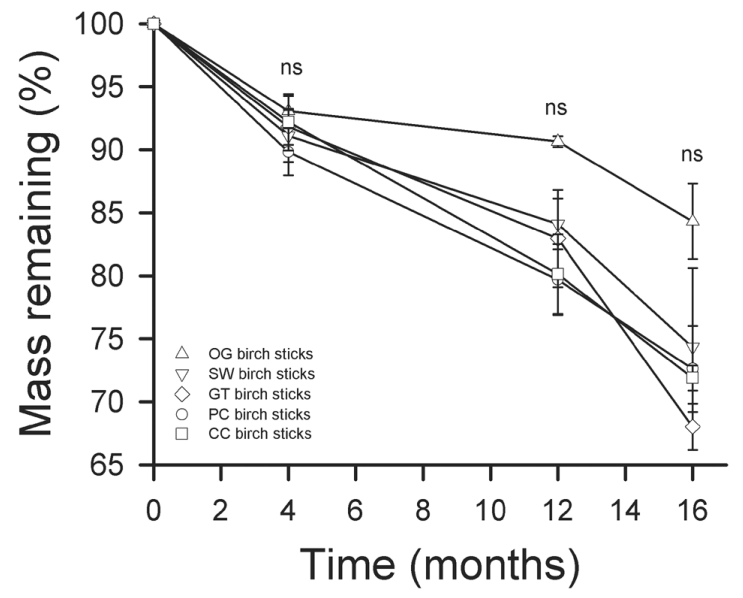

Fig. 4. Mean mass loss $( \pm S E)$ over 16 months from birch sticks buried $\sim 5 \mathrm{~cm}$ below the soil surface over the first four years after harvesting (1994-1997) in all five treatment plots at MASS (OG = old-growth, SW = shelterwood, GT = green tree, $\mathrm{PC}=$ patch cut, $\mathrm{CC}=$ clearcut; $p=0.78,0.06$ and 0.08 for 4 , 12 and 16 months, respectively].

weeks (June-Sept.) over the fourth and fifth growing seasons (1997-98). Collectors were cleaned and chemical analyses and $\mathrm{N}$ flux calculations were carried out as for soil solution samples.

\section{Results}

Litter inputs (Fig. 2) were usually significantly greater in treatments with the most trees present $\left(1840\right.$ and $1111 \mathrm{~kg} \mathrm{ha}^{-1} \mathrm{yr}^{-1}$ averaged over five years in old-growth and shelterwood treatments, respectively), and were similar amongst the other three treatments $\left(<200 \mathrm{~kg} \mathrm{ha}^{-1} \mathrm{yr}^{-1}\right.$ in four out of the five years). Annual litterfall in the old-growth forest ranged from 800 to $2500 \mathrm{~kg} \mathrm{ha}^{-1} \mathrm{yr}^{-1}$ during the study period.

Within the limitations of the design of the study, the decomposition rate of hemlock needles was significantly greater in the old-growth forest than in some of the other treatments over the first three years, but not after the fourth year (Fig. 3). It tended to be the slowest in the clearcut, patch cut and green tree treatments, depending on the year, and intermediate in the shelterwood treatment (although never significantly different from the old-growth forest). There were no significant differences in decomposition rate of forest floor material among the treatments. Mass loss for birch sticks buried at $\sim 5 \mathrm{~cm}$ tended to be slowest in the old-growth forest (Fig. 4), in contrast to hemlock needle litter, but treatment differences were not significant ( $p=0.78$ at 4 months, 0.06 at 12 months and 0.08 at 16 months).

Mean monthly soil temperatures peaked in August (data not shown) and were about $2^{\circ} \mathrm{C}$ lower in the old-growth forest $\left(11.7^{\circ} \mathrm{C}\right)$ than all the other treatments, which were about the same $\left(13.4\right.$ to $\left.13.9^{\circ} \mathrm{C}\right)$. There were no treatment effects for annual GDD $>0^{\circ} \mathrm{C}(p=0.35), \mathrm{GDD}>5^{\circ} \mathrm{C}(p=0.17)$ or GDD $>7.5^{\circ} \mathrm{C}(p=0.08)$, but there were for GDD $>10^{\circ} \mathrm{C}(p=$ $0.03)$, when accumulated heat sums were greater in the green tree $\left(225^{\circ} \mathrm{C} \mathrm{yr} r^{-1}\right)$ than old-growth $\left(47^{\circ} \mathrm{Cyr}^{-1}\right)$ treatments (Fig. 5). 


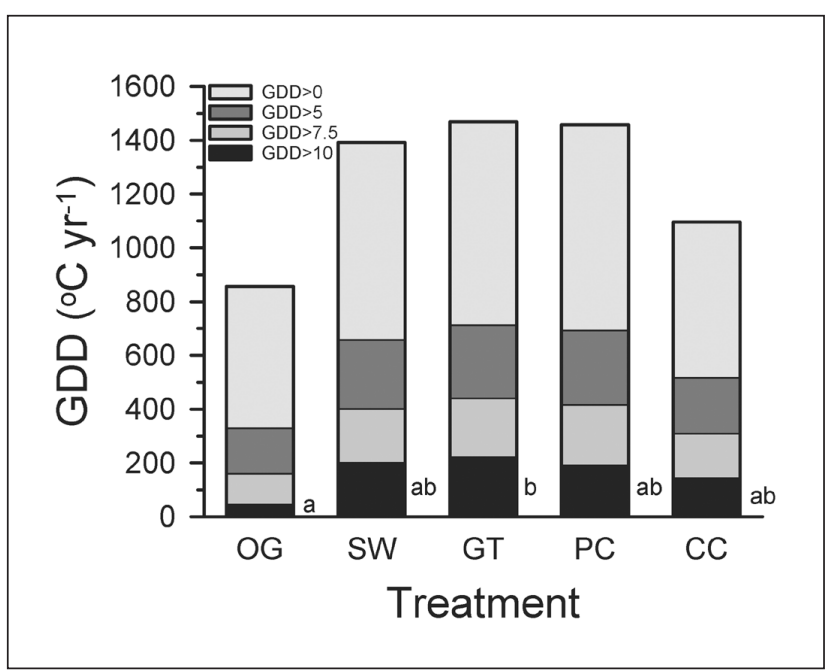

Fig. 5. Mean accumulated growing degree days (GDD) above 0 , $5,7.5$ and $10^{\circ} \mathrm{C}$ at $5 \mathrm{~cm}$ below the soil surface over the first seven-years after harvesting (1993-1999) in all five treatments at MASS over the study period $\mathrm{COG}=$ old-growth, SW = shelterwood, $\mathrm{GT}=$ green tree, $\mathrm{PC}$ = patch cut, $\mathrm{CC}$ = clearcut; there was only a significant treatment effect for $\mathrm{GDD}>10^{\circ} \mathrm{C}$, and means with same letters beside $\mathrm{GDD}>10^{\circ} \mathrm{C}$ bars are not significantly different].

Intermediate treatments did not differ from the other two (203, 194 and $146^{\circ} \mathrm{C} \mathrm{yr}^{-1}$ for shelterwood, patch cut and clearcut treatments, respectively). GDD $>10^{\circ} \mathrm{C}$ was the only accumulated heat sum parameter for which there were ever significant treatment differences, and these occurred at every depth sampled $(5,15,30$ and $50 \mathrm{~cm}$; data not shown).

Both actual and modelled moisture contents in the LF layer of the forest floor five years after harvesting (1998) tended to be greatest in the old-growth forest, while the moisture content in the shelterwood was slightly greater than that in the clearcut treatment (Fig. 6). However, this pattern was reversed in the deeper $\mathrm{H}$ layer, where the moisture content tended to be greatest in the clearcut, and slightly greater in the shelterwood treatment than the old-growth forest.

Gross nitrate production rates tended to be higher in the old-growth forest than in the clearcut four years after harvesting (1997), but were the same in the following year (Fig. 7). Conversely, ammonium production rates tended to be higher in the clearcut than the old-growth forest, but only for June. For all treatments, gross $\mathrm{N}$ production rates were high when consumption rates were also high. There was net consumption of nitrate four years post-harvest (1997) in June, but net production two months later in August. There was net ammonium production in June in the clearcut but not in the old-growth forest or shelterwood; in August, there was net immobilisation of ammonium in all treatments. Addition of acetylene (which blocks autotrophic nitrification) did not affect gross nitrification rate five years after harvesting (August 1998; Fig. 7), indicating that heterotrophic populations were the predominant contributors to nitrification.

Foliar $\mathrm{N}$ concentrations in planted seedlings that were monitored annually (of which results in Mitchell 2001 and Mitchell et al. 2003 are for one year of this annual sampling) tended to decrease between two and six years after harvesting,

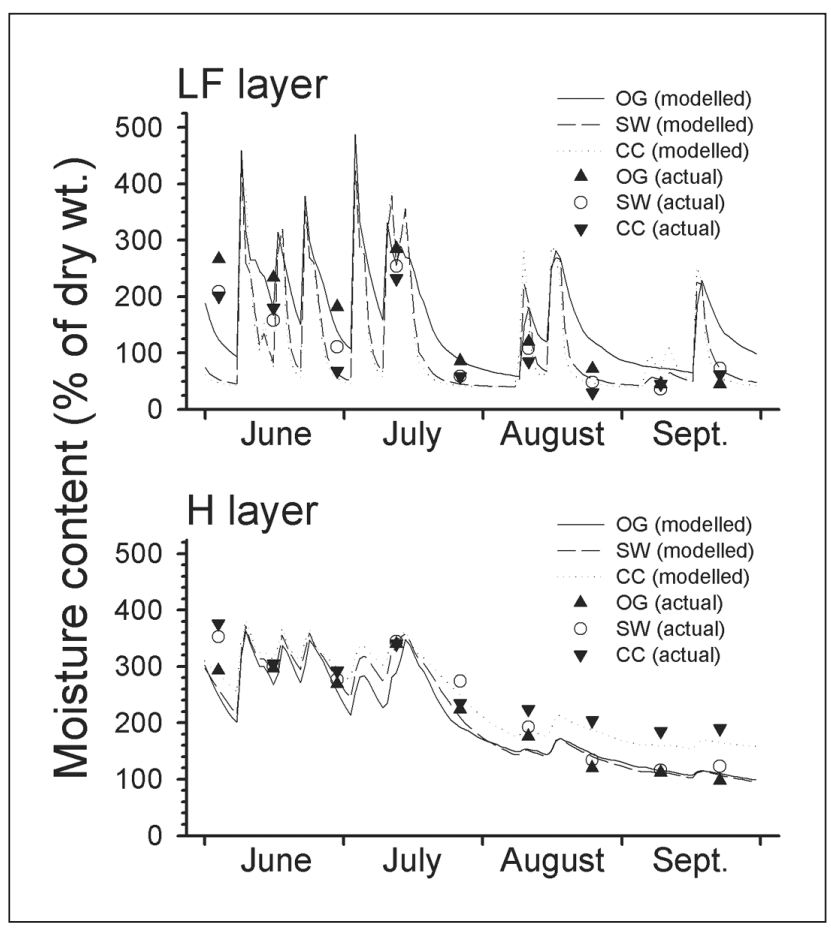

Fig. 6. Actual and simulated (ForWaDy) moisture content (as percent of dry mass) of LF and $\mathrm{H}$ horizons in old-growth (OG), shelterwood (SW) and clearcut (CC) treatment plots during the fifth growing season after harvesting (1998) at MASS.

at which time they were below the deficiency level for firs and the adequate level for western hemlock; treatment effects were never statistically significant (Fig. 8). Similarly, foliar N concentrations in naturally regenerated hemlock and fir monitored annually in harvested treatments generally increased from two to three years after harvesting, and then decreased.

The amount of total-N leached below the rooting zone $(25 \mathrm{~cm})$ tended to increase with the intensity of stand removal $(\mathrm{CC}>\mathrm{SW}>\mathrm{OG})$ for the first five years after harvesting (Fig. 9). However, losses after shelterwood harvesting were significantly greater than those from the undisturbed oldgrowth forest only in the second year after harvesting, at which time they were the same as losses after clearcutting. In the third, fourth and fifth years after harvesting, losses from the rooting zone in the clearcut treatment were significantly greater than those from both the old-growth and shelterwood treatments. Atmospheric inputs (i.e., rainfall, or bulk deposition) were estimated to be $\sim 1 \mathrm{~kg} \mathrm{ha}^{-1} \mathrm{yr}^{-1}$.

\section{Discussion}

The flows and connections between all of the $\mathrm{N}$ cycling processes studied at MASS are represented in Fig. 10. (N.B. we use $\mathrm{N}$ mineralization to refer to the combination of ammonification $\left(=\mathrm{NH}_{4}-\mathrm{N}\right.$ production $)$ and nitrification $\left(=\mathrm{NO}_{3}-\mathrm{N}\right.$ production) rather than to just ammonification.) Although the studies did not cover the full range of known $\mathrm{N}$ cycling processes, the knowledge generated can be used to answer four key questions that are relevant at MASS, and may have applicability in similar montane forest ecosystems in the Pacific Northwest of North America. 

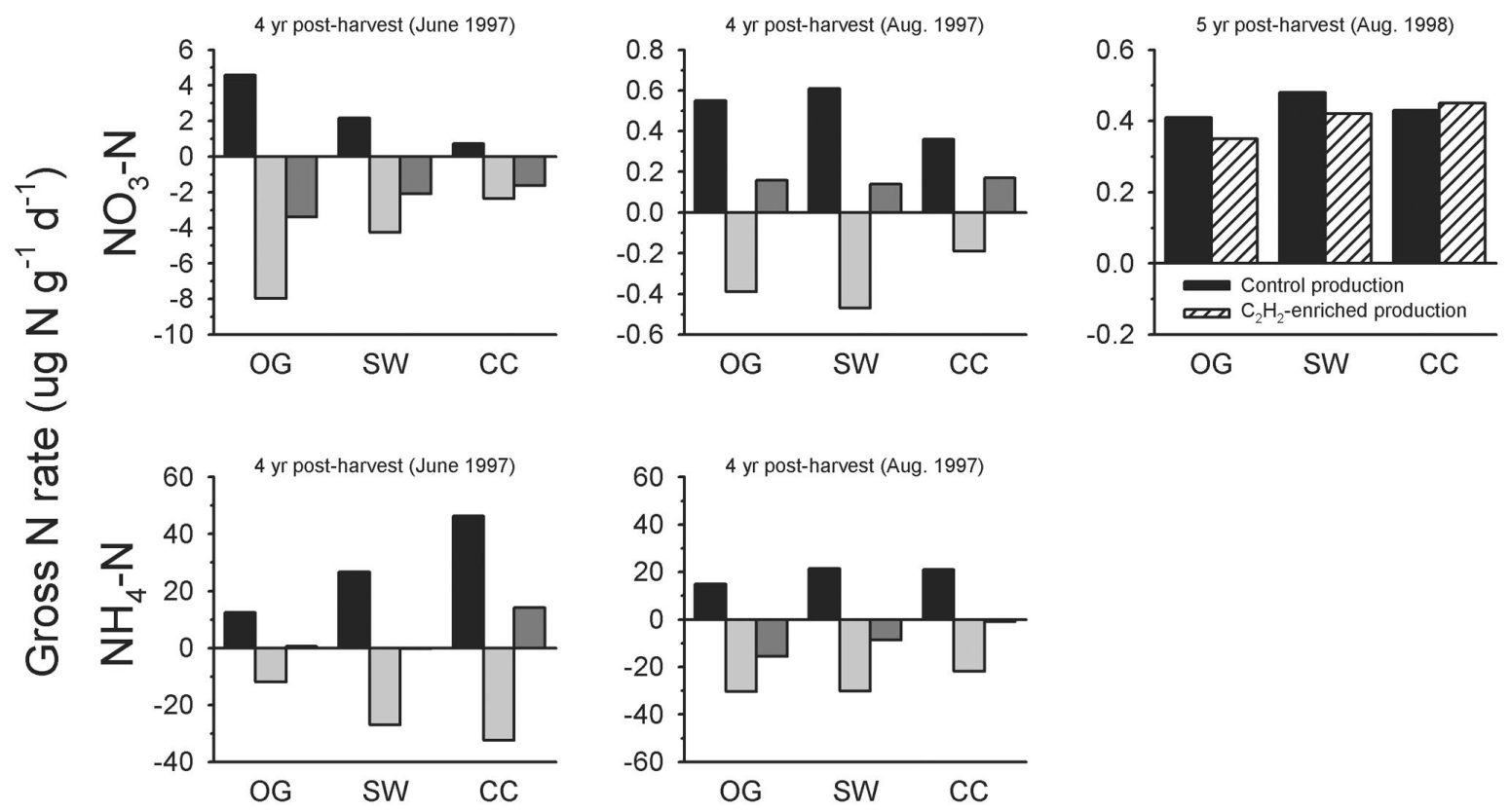

$\longrightarrow$ Production $\rightleftharpoons$ Consumption $\rightleftharpoons$ Production - Consumption

Fig. 7. Gross mineral N transformations in forest floor samples from the old-growth (OG), shelterwood (SW) and clearcut (CC) treatment plots, collected four (June 1997, August 1997) and five years (August 1998) after harvesting (June 1997 data after Grenon et al. 2004). Results for August 1998 are for gross $\mathrm{NO}_{3}-\mathrm{N}$ production only, and includes test for autotrophic activity by addition of acetlyene, which blocks autotrophic metabolism.

\section{What are the effects of clearcutting on $\mathbf{N}$ cycling?}

There was a trend towards higher $\mathrm{N}$ mineralization in the forest floor at two and four years after clearcutting at MASS compared to old-growth stands in both lab and field incubation studies, but results were rarely significant (Prescott 1997, Bradley et al. 2000). The same trend was evident in the mineral soil, although mineralization rates were an order of magnitude less than for the forest floor (Prescott 1997). Initial differences in nitrogen concentrations in the soil solution between old-growth and clearcut treatments at MASS tended to become negligible by five years after cutting (unpublished data used to derive fluxes in Feller et al. 2000 and present study), although differences in fluxes of $\mathrm{N}$ through the soil (Fig. 9) were accentuated by greater rates of movement of water in the clearcut treatment (derived from Fig. 6). Similar results were found in a chronosequence of submontane (550-600 m asl) forest sites on Vancouver Island, where ammonium showed relatively little response to harvesting and elevated nitrate concentrations found on a five-year-old cutover were not evident on an eight-year-old or on older cutovers (Bradley et al. 2002a).

The observed increases in net $\mathrm{N}$ mineralization would be expected to result in enhanced seedling growth, as net $\mathrm{N}$ mineralization is a useful index (rather than direct measure) of plant-available N (Schimel and Bennett 2004). Although the magnitude of changes in $\mathrm{N}$ mineralization resulting from clearcutting at MASS were relatively small and short-lived compared to sites elsewhere (e.g., Rosén et al. 1996, Titus et al. 1998), did these changes result in increased seedling growth?
Any increases in seedling foliar $\mathrm{N}$ concentrations after clearcutting appear to last for up to four years after harvesting (Fig. 8; Koppenaal and Hawkins 2000, Hawkins and Moran 2003, Maynard and Senyk 2004), which is fairly consistent with our results for $\mathrm{N}$ mineralization and availability in the soil. Changes in foliar $\mathrm{N}$ concentrations up to six years after harvesting suggest a possible response to a small assart effect that lasted from two to four years after harvesting. Early growth rates of planted (Mitchell 2001; Mitchell et al. 2003, 2004) and naturally regenerated seedlings (Hawkins and Moran 2003) on the clearcut treatment suggest that they are growing well in the ensuing nutritional environment, with no evidence of seedling growth check at this stage of development.

However, foliar $\mathrm{N}$ concentrations six years after harvesting are below deficiency or adequacy levels for both true firs (Powers 1983) and hemlock (Ballard and Carter 1986). Furthermore, $\mathrm{N}$ foliar concentrations for amabilis fir on a clearcut adjacent to MASS decreased from $~ 1.3 \%$ for naturally regenerated seedlings and $1.7 \%$ for planted seedlings at five to six years after harvesting (which is similar to values for MASS; see Fig. 8), to $0.8 \%$ at the end of the ninth growing season after harvesting (Hawkins et al. 2002). This suggests that further declines in foliar $\mathrm{N}$ concentration at MASS are possible, at least in the clearcut treatment. Fertilization studies indicated that $\mathrm{N}$ limits growth at the MASS site (Hawkins and Moran 2003, Mitchell et al. 2004). Further monitoring will therefore be required to determine whether seedlings will become N-deficient and growth check will be expressed 12 to 15 years after harvesting, as is commonly observed on these sites. 


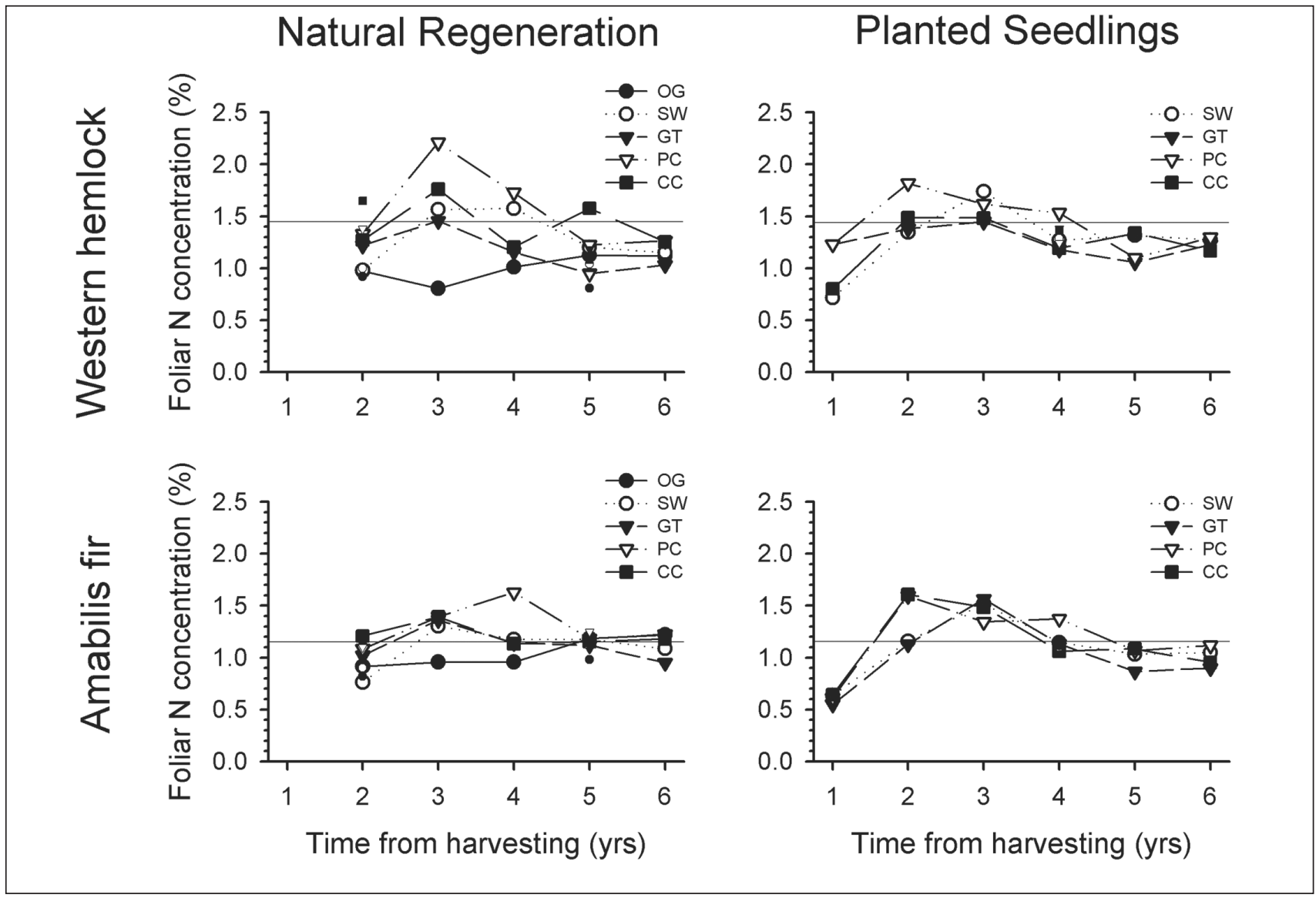

Fig. 8. Annual autumn foliar $N$ concentrations in naturally regenerated and planted western hemlock and amabilis fir seedlings for the first six years after harvesting. Foliar N concentrations at the time of planting were $2.15 \%$ and 1.99\% for western hemlock and amabilis fir, respectively. Additional data for naturally-regenerated seedlings at two and five years (Koppenaal and Hawkins 2000 ; see Table 2 for statistical differences at two years) and planted seedlings at four years (Maynard and Senyk 2004; undisturbed microsites) are included as single points, represented by smaller symbols. Horizontal line at 1.15\% indicates deficiency level for true fir (Powers 1983), and line at 1.45\% indicates adequate level for western hemlock (Ballard and Carter 1986). (OG = old-growth, SW = shelterwood, GT = green tree, $\mathrm{PC}=$ patch cut, $\mathrm{CC}=$ clearcut.]

What are the mechanisms that led to the clearcutting effects? Litterfall, fine root death and leaching from the canopy are the main pathways by which $\mathrm{N}$ returns to the forest floor from old-growth trees. First, the amount of litterfall was reduced at harvesting (Fig. 2), depending on the amount of basal area removed, and therefore the periodic input of this $\mathrm{N}$ source was decreased, or initially eliminated in the case of

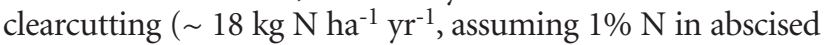
needles, based on Tarrant et al. 1951 and Keenan et al. 1995). Then, while it might have been assumed that the forest floor would decompose more quickly in the clearcut than in the old-growth forest because of increased forest floor temperature (Fig. 5), this was not the case for surface needle litter (Fig. 3). It is possible that periodic drying of the litter layer surface limited surface litter decomposition (Whitford et al. 1981; cf. differences between LF and H horizons in Fig. 6). However, the opposite trend was found for buried birch sticks (Fig. 4 ; lowest $p$-value $=0.06$ at 12 months), with increased soil moisture deeper in the forest floor and higher temperatures on the clearcut. Similar trends in decomposition rates were found at different soil depths between stands and clearcuts in two other forests in the Coastal Western Hemlock zone on Vancouver Island using standard materials (Binkley 1984, Martin et al. 2002).

There are several possible explanations for our finding that $\mathrm{N}$ mineralization increased somewhat with clearcutting. It may be that decomposition below the soil surface increased with clearcutting and led to an increase in $\mathrm{N}$ mineralization that, because of reduced plant uptake on the clearcut, led to increased leaching from the rooting zone. Alternatively, it is possible that reduced litterfall and detrital inputs could have led to a reduction in available $C$ (an energy source for heterotrophic decomposer organisms) and hence reduced microbial activity and uptake of mineral $\mathrm{N}$, resulting in an increase in available $\mathrm{N}$ in the soil (Hart et al. 1994). At MASS, the microbial activity in the forest floor (e.g., basal respiration, microbial biomass, metabolic quotient) was indeed lower in the clearcut than in the old-growth forest (Bradley et al. 2001), as has also been observed at lower elevations in salal-cedar-hemlock forests in the Coastal Western Hemlock zone (Chang and Trofymow 1996). However, it is not absolute rates of microbial activity alone that determine mineral $\mathrm{N}$ availability, as microbial communities consume as well as produce mineral N. It is the net result of gross production 


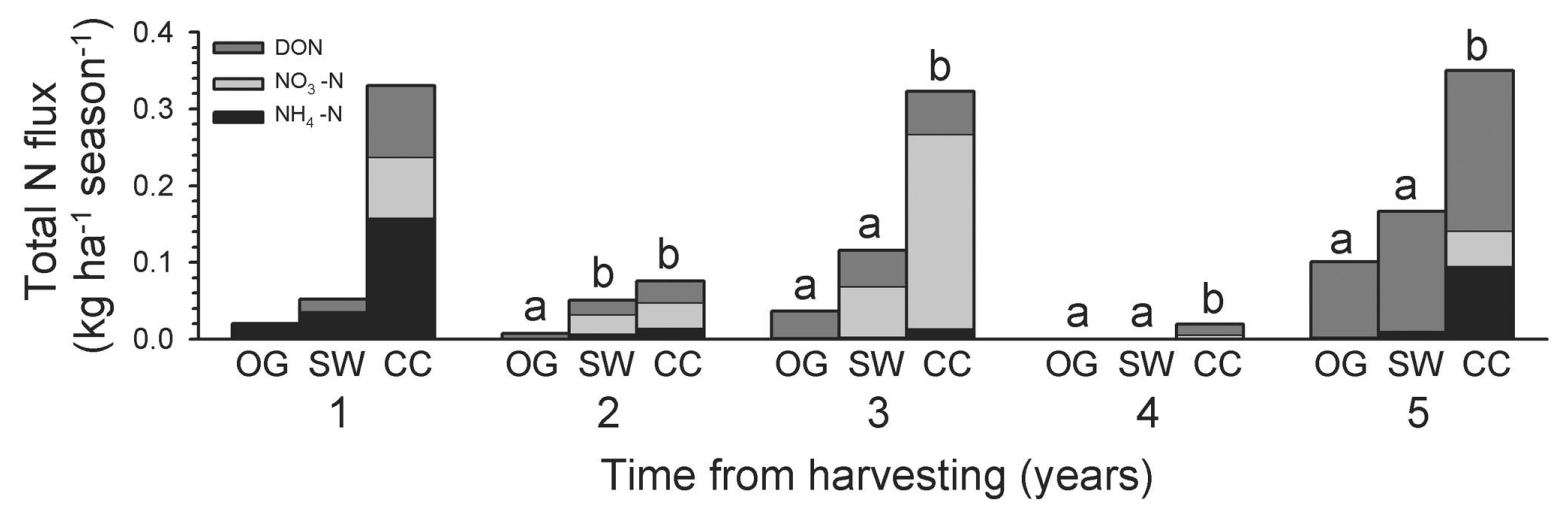

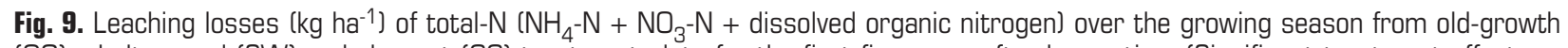
(OG), shelterwood (SW) and clearcut (CC) treatment plots for the first five years after harvesting. (Significant treatment effects are for total $\mathrm{N}=\mathrm{DON}+\mathrm{NH}_{4}-\mathrm{N}+\mathrm{NO}_{3}-\mathrm{N}$; there were no differences for individual forms of $\mathrm{N}$ in any year; within a given year, mean total $\mathrm{N}$ values with same letters are not significantly different.]

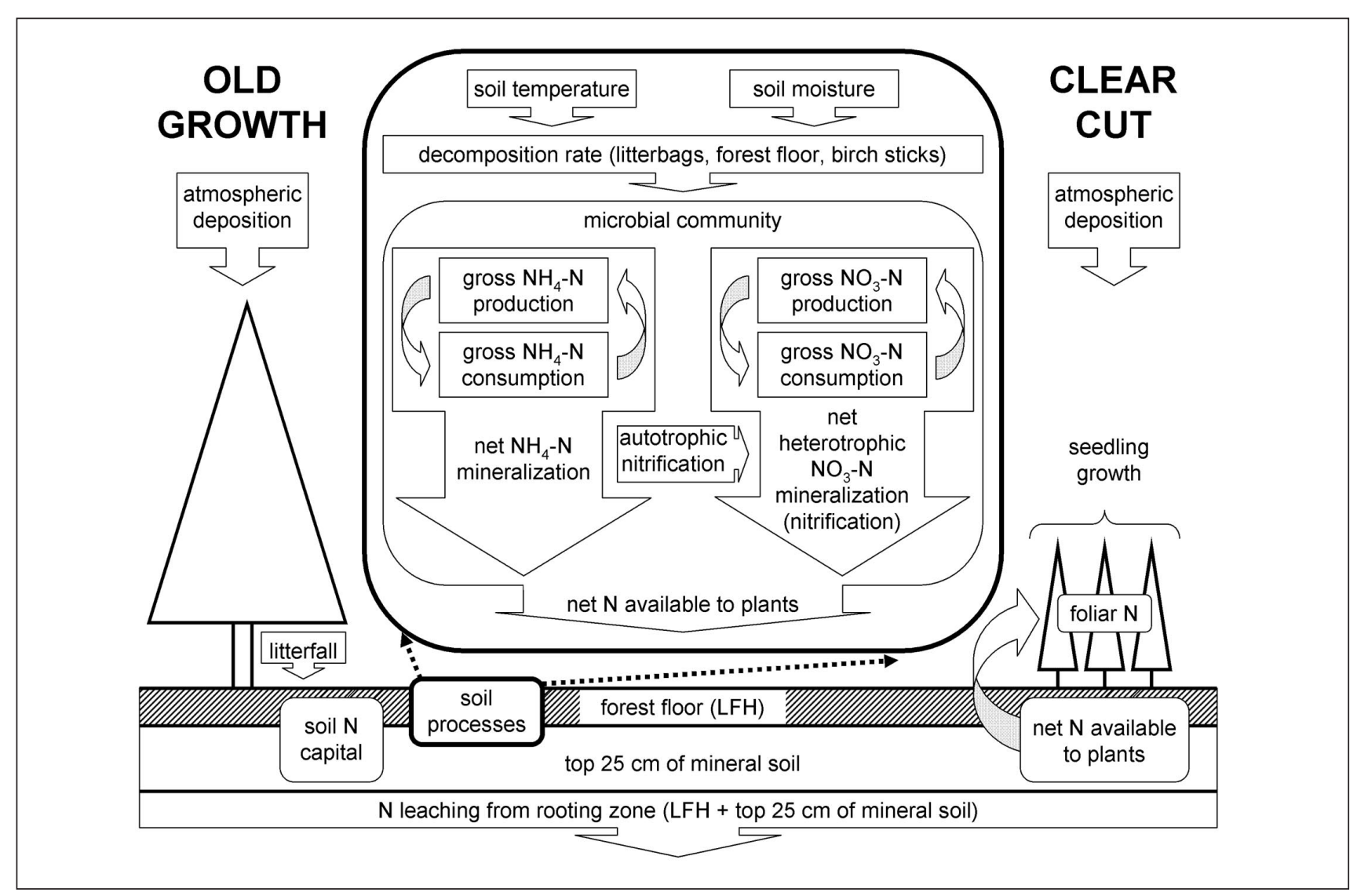

Fig. 10. Flow diagram showing $\mathrm{N}$ cycling processes and fluxes studied at MASS.

minus gross consumption that is measured as an index of extractable, or plant available mineral $\mathrm{N}$ (see recent review by Booth et al. 2005, and Schimel and Bennett 2004). For example, although net nitrate availability is generally assumed to be greater on clearcuts than in forests, gross nitrate production can be high in undisturbed coniferous forests (Stark and Hart 1997), and at MASS it tended to be greater in the old-growth forest than in the clearcut in June (and less distinctly so in August) four years after harvesting (Fig. 7). Further research is required to elucidate which $\mathrm{N}$ cycling processes predomi- 
nated in the clearcut treatment at MASS. Although planted seedlings can respond positively to control of competing species (Mitchell et al. 2003, 2004), the effect of early seral species (Vaccinium spp., Epilobium angustifolium) on $\mathrm{N}$ uptake and cycling on the clearcut is also not known.

All field and incubation studies at MASS (Fig. 7; Prescott 1997, Bradley et al. 2000) showed that dissolved inorganic nitrogen $\left(\mathrm{DIN}=\mathrm{NH}_{4}-\mathrm{N}+\mathrm{NO}_{3}-\mathrm{N}\right)$ after clearcutting was predominantly ammonium and not nitrate (except at $\sim 25$ $\mathrm{cm}$ deep in the mineral soil over the first three years after clearcutting, as sampled using porous cup lysimeters). This is consistent with findings elsewhere in the Coastal Western Hemlock zone on Vancouver Island (Bradley et al. 2002a, Kimmins et al. 2002), but contrasts with ecosystems where nitrate predominates after disturbance (e.g., Swank et al. 2001). The results from MASS also suggest that ammonium is not readily converted to nitrate by autotrophic organisms at this site (Fig. 7), notwithstanding the limitations of the acetylene method used (De Boer and Kowalchuck 2001). The nitrate found at MASS was therefore likely produced directly by heterotrophic organisms as they decomposed organic matter, rather than by autotrophs chemically converting ammonium to nitrate to obtain their energy requirements, as has been found elsewhere in some acid forest soils (see review by De Boer and Kowalchuck 2001). Furthermore, gross N transformations showed that increases in net nitrification after harvesting at MASS were the result of decreased gross nitrate consumption, as gross nitrate production actually decreased with harvesting (Fig. 7).

Overall, notable $\mathrm{N}$ cycling mechanism findings at MASS include (i) decomposition rates at the soil surface were greater in old-growth than clearcut, but at $\sim 5 \mathrm{~cm}$ down the soil profile were greater in the clearcut, (ii) greater microbial activity in the old-growth than in the clearcut, (iii) greater gross nitrification in the old-growth than in the clearcut (clearer on some dates than others), (iv) predominance of ammonium rather than nitrate after harvesting, and (v) the lack of autotrophic nitrification in the different harvesting treatments.

\section{Do alternative silvicultural systems mitigate the effects of clearcutting?}

If clearcutting causes changes in $\mathrm{N}$ cycling, does some level of tree retention following different harvesting patterns moderate the amount of change? Or do alternative silvicultural systems behave more like old-growth forests or more like clearcuts? The most common treatment comparisons at MASS were between the old-growth forest, shelterwood (25\% basal area retention) and clearcut treatments. There was a wide range of responses in $\mathrm{N}$ cycling processes to these two different intensities of disturbance at MASS: some processes in the shelterwood treatment were similar to those in the oldgrowth forest, some were similar to those in the clearcut treatment, some were midway between the two extreme treatments, and for some there were no differences between any of the three main treatments (Table 2). The two other variable retention treatments (green tree and patch cut) were only compared for a small number of variables, and tended to be intermediate between the shelterwood and clearcut treatments in almost all cases. The notable exceptions to this include decomposition of hemlock needles (which tended to decompose more slowly in patch cut and green tree treat- ments, especially soon after harvesting) and foliar $\mathrm{N}$ concentrations in planted seedling (which did not differ between treatments).

One of the key objectives of the modified shelterwood treatment was to retain some level of old-growth features, as reserves. This objective appears to have been partially achieved, as some of the most fundamental $\mathrm{N}$ cycling processes (e.g., most net $\mathrm{N}$ mineralization results, $\mathrm{H}$ layer moisture content) were relatively unaffected by shelterwood harvesting. This may have resulted in a lack of effect on higher-level processes that integrate more detailed processes (often measured over days or weeks) over longer time periods (growing seasons, years). The relative lack of $\mathrm{N}$ mineralization response to shelterwood harvesting can be expected to have led to a lack of treatment effect on $\mathrm{N}$ availability to plants. This appears to have been the case, as shelterwood harvesting (as well as all other treatments) had little effect on foliar $\mathrm{N}$ concentrations in planted and naturally regenerated seedlings. Nitrogen not taken up by plants would be expected to either remain in the plant-soil system, or be leached below the rooting zone. While there was a tendency for shelterwood harvesting to increase $\mathrm{N}$ leaching from the rooting zone, there were no significant differences between the shelterwood treatment and the old-growth forest in four out of five years. It would therefore seem that although some $\mathrm{N}$ cycling processes were sensitive to shelterwood harvesting, the accumulated effects of the processes were not clearly evident in either increased seedling foliar $\mathrm{N}$ concentration or in greatly increased leaching from the rooting zone.

There are few studies comparing effects of alternative harvesting of conifers on soil processes in coniferous forests. However, two that have been completed showed even smaller harvesting effects than observed at MASS. For example, Barg and Edmonds (1999) did not find any differences in $\mathrm{N}$ mineralization in field incubations or soil microbial biomass between an uncut Douglas-fir forest in the Pacific Northwest and green tree retention and clearcut treatments. Similarly, Siira-Pietikäinen et al. (2001) found that decomposer communities in a Picea abies forest floor in Finland were barely affected by any form of harvesting (clearcut, selection, retention, and gap felling), with only clearcutting sometimes causing differences in communities compared to the unharvested forest. At MASS, it is interesting to note that $\mathrm{C}$ utilization patterns (Biolog plates) were distinctly different in the three treatments studied but that shelterwood was not intermediate between the clearcut or old-growth treatments, unlike other microbial parameters where the shelterwood was usually much like the clearcut(Bradley et al. 2001).

Increased $\mathrm{N}$ leaching from upper soil horizons is one of the most important potential impacts of harvesting on forest and aquatic ecosystems. The findings at MASS are similar to those of Martin and Harr (1989), who found that shelterwood harvesting (60\% basal area retention $c f .25 \%$ at MASS) on the western slopes of the Cascade Mountains in Oregon had no apparent impact on stream exports of $\mathrm{N}$, while losses after clearcutting increased only very slightly (by $0.1 \mathrm{~kg}$ dissolved organic nitrogen (DON) $+\mathrm{NH}_{4}-\mathrm{N} \mathrm{ha}^{-1} \mathrm{yr}^{-1}$ over a 10year post-harvest period). Similarly, Stark (1979) found that while clearcutting increased nitrate levels more than shelterwood cutting in Douglas-fir-larch forests in Montana, neither harvesting system had much impact on losses. 


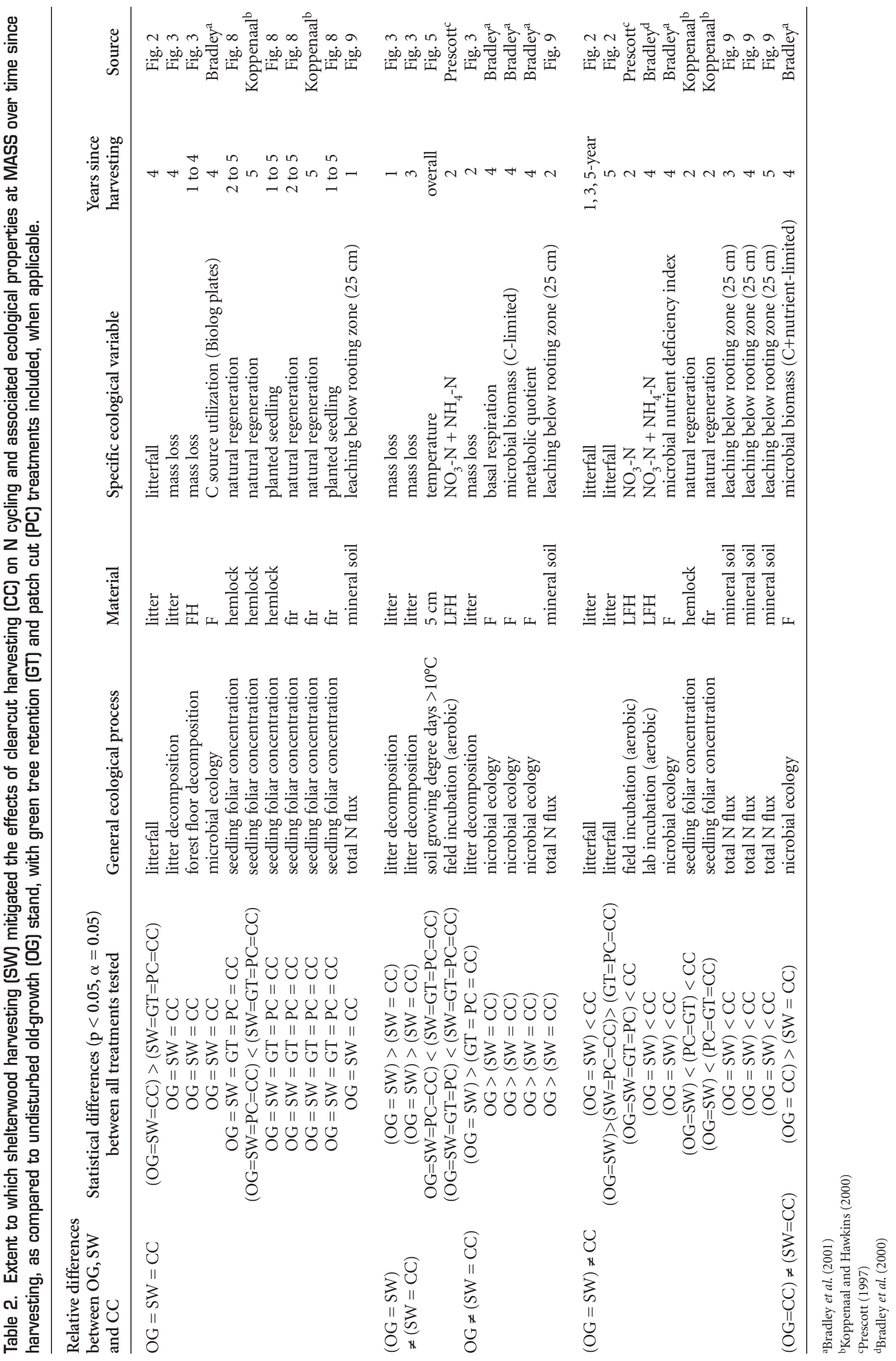


Did any reductions in $\mathrm{N}$ mineralization and availability found in the retention treatments (shelterwood, green tree) compared to the clearcut treatment result in reduced tree seedling response? Fertilization studies indicate that $\mathrm{N}$ limits growth at the MASS site (Hawkins and Moran 2003, Mitchell et al. 2004), but foliar $\mathrm{N}$ concentrations were only different among treatments for naturally-regenerated western hemlock two and five years after harvesting (Koppenaal and Hawkins 2000) and for naturally-regenerated fir shoots five years after harvesting (Hawkins and Moran 2003). Furthermore, foliar $\mathrm{N}$ was a poor predictor of early seedling growth at MASS when all silvicultural systems treatments were considered (Mitchell et al. 2003). The poorer five-year growth of naturally-regenerated fir (Hawkins and Moran 2003) and seven-year growth of planted seedling (Mitchell et al. 2004) on retention treatments therefore cannot be attributed solely to differences in soil $\mathrm{N}$ processes between treatments. There is also a $47 \%$ reduction in available light in the shelterwood treatment, which will have a large effect on seedling growth (Mitchell 2001). Conserving one limiting resource $(\mathrm{N})$ through partial retention of the overstory may therefore lead to the lack of another limiting resource (light).

\section{What is the potential for loss of site productivity after harvest- ing these sites?}

Perhaps the most important question regarding $\mathrm{N}$ cycling is whether or not long-term site productivity will be adversely affected by leaching losses after clearcut harvesting. Overall, the net fluxes of total $\mathrm{N}$ from below the rooting zone $(25 \mathrm{~cm}$ in the mineral soil) in the clearcut treatment at MASS were small $\left(<0.3 \mathrm{~kg} \mathrm{ha}^{-1}\right.$ over the growing season for the first five years after harvesting). Even assuming year-round leaching at this rate, it is likely that annual losses of $\mathrm{N}$ from the rooting zone through leaching were $\sim 1 \mathrm{~kg} \mathrm{ha}^{-1} \mathrm{yr}^{-1}$. (Using a different sampling approach and model for estimating water flux on the same site, Feller et al. (2000) estimated annual total N leaching losses of 1.4, 2.3 and $4.1 \mathrm{~kg} \mathrm{ha}^{-1} \mathrm{yr}^{-1}$ for the first three years following treatment from the old-growth, shelterwood, and clearcut, respectively. Differences in estimates may have resulted because (i) ForWaDy estimated 25\% less annual water flux from clearcut and 50\% less water flux from oldgrowth and shelterwood than the model used in Feller et al. (2000), (ii) extreme droughts occurred in the fourth and fifth sampling seasons, thus greatly reducing nutrient flux and the resultant arithmetic mean over the first five years after harvesting, and (iii) analysis in the present study was limited to equal sampling periods so that years could be compared.) The estimated value of $\sim 1 \mathrm{~kg} \mathrm{ha}^{-1} \mathrm{yr}^{-1}$ is similar to those reported for some Pacific Northwest conifer sites (Feller and Kimmins 1984, Martin and Harr 1989), less than for some European sites (Kimmins et al. 1985) and a New Brunswick watershed (Krause 1982, Jewett et al. 1995), and much less than for another site in the Coastal Western Hemlock zone on Vancouver Island (Bradley et al. 2002b, Kimmins et al. 2002) and alder sites (see literature review tables in Kimmins et al. 1985). Nitrogen in the soil at the MASS site seems to be particularly resistant (sensu Halpern 1988) to clearcut harvesting disturbances, which emphasizes the care that must be taken in generalizing about disturbance effects on N cycling (Grenon et al. 2004).

The potential for $\mathrm{N}$ losses and long-term site degradation because of clearcutting at MASS can be simplistically estimated by comparing $\mathrm{N}$ inputs with $\mathrm{N}$ outputs in leaching (Table 3). The two main inputs to sites are wet and dry atmos-

Table 3. Nitrogen budget for MASS (based on leaching outputs following clearcutting).

\begin{tabular}{|c|c|c|c|c|c|}
\hline Measurement period & & Variable & $\begin{array}{c}\text { Estimated } \\
\left(\mathrm{kg} \mathrm{N} \mathrm{ha}^{-1} \mathrm{yr}^{-1}\right)\end{array}$ & $\begin{array}{c}\text { Minimum } \\
\left(\mathrm{kg} \mathrm{N} \mathrm{ha}^{-1} \mathrm{yr}^{-1}\right)\end{array}$ & $\begin{array}{c}\text { Maximum } \\
\left(\mathrm{kg} \mathrm{N} \mathrm{ha}^{-1} \mathrm{yr}^{-1}\right)\end{array}$ \\
\hline \multirow{6}{*}{ Short-term estimate } & \multirow{4}{*}{$\mathrm{N}$ inputs } & Atmospheric deposition $^{\mathrm{a}}$ & +2 & +1 & +2.2 \\
\hline & & Fixation in $\mathrm{CWD}^{\mathrm{b}}$ & +1 & +0.3 & +1.4 \\
\hline & & Fixation in forest floor ${ }^{\mathrm{c}}$ & +1 & +0 & +1 \\
\hline & & Annual inputs & +4 & +1.3 & +4.6 \\
\hline & N outputs ${ }^{\mathrm{d}}$ & Annual leaching ${ }^{\mathrm{e}}$ & -1 & $-0.2(?)$ & $-1(?)$ \\
\hline & \multicolumn{2}{|l|}{ Balance } & +3 & $+0.3^{\mathrm{f}}$ & $+4.4^{\mathrm{g}}$ \\
\hline
\end{tabular}

\begin{tabular}{llc} 
Long-term estimate & $\begin{array}{l}\text { Soil capital (to } 30 \mathrm{~cm})^{\mathrm{h}} \\
\text { Annual accretion since glaciation }\end{array}$ & $\begin{array}{l}11400 \mathrm{~kg} \mathrm{~N} \mathrm{ha}^{\mathrm{i}} \\
+1 \mathrm{~kg} \mathrm{~N} \mathrm{ha}^{-1} \mathrm{yr}^{-1}\end{array}$ \\
\hline Export in logs at clearcutting & $250 \mathrm{~kg} \mathrm{ha}^{-1}$
\end{tabular}

\footnotetext{
${ }^{\mathrm{a}} \sim 0.5 \mathrm{~kg} \mathrm{~N} \mathrm{ha}^{-1} \mathrm{yr}^{-1}$ in bulk deposition measured over growing season from May-Oct. (unpublished data), during which time $0.83 \mathrm{~kg} \mathrm{~N}$ ha ${ }^{-1}$ was collected at the nearest NatChem site over the study years, while $2.2 \mathrm{~kg} \mathrm{~N} \mathrm{ha}^{-1}$ were deposited annually (Ro 2002). Estimated bulk deposition of 2.2 to $5.0 \mathrm{~kg} \mathrm{~N}^{-1} \mathrm{yr}^{-1} \mathrm{were}$ found over a 3-year period at Mt. Arrowsmith, south of the MASS site (Feller 1997).

bLarsen et al. (1982), Silvester et al. (1982), Sollins et al. (1987), Cushon and Feller (1989).

'Heath et al. (1988), Cushon and Feller (1989).

${ }^{\mathrm{d}}$ Assumes minimal outputs in biomass at harvesting; denitrification not included.

${ }^{e}$ Based on $<0.1 \mathrm{~kg} \mathrm{~N} \mathrm{ha}^{-1}$ growing season ${ }^{-1}$ in minimum years $\left(2,4\right.$ years after harvesting) and $<0.4 \mathrm{~kg} \mathrm{~N}^{-1}$ growing season $^{-1}$ in peak years $(1,3,5$ years after harvesting) and therefore assuming $<0.2$ and $<1 \mathrm{~kg} \mathrm{~N} \mathrm{ha}^{-1} \mathrm{yr}^{-1}$ as annual minimum and maximum rates, respectively; see also leaching fluxes for the first three years at the MASS site in Feller et al. (2000), and other sites in Krause (1982), Feller and Kimmins (1984), Kimmins et al. (1985), Martin and Harr (1989), Jewett et al. (1995), Titus et al. (1998).

${ }^{\mathrm{f}}$ Minimum balance assumes minimum input minus maximum output.

gMaximum balance assumes maximum input minus minimum output.

hMaynard and Senyk, unpublished data.

${ }^{\mathrm{i} A s s u m i n g} \sim 10000$ years since glaciation at the MASS site.

${ }^{j}$ Estimated for 400-year-old stand in the Coastal Western Hemlock zone (Kimmins et al. 2002).
} 
pheric deposition (i.e., bulk deposition or bulk precipitation) and $\mathrm{N}$ fixation. At the MASS site, inputs from atmospheric deposition and $\mathrm{N}$ fixation in coarse woody debris (CWD) and the forest floor were estimated to be $\sim 4 \mathrm{~kg} \mathrm{ha}^{-1} \mathrm{yr}^{-1}$ (based on published values in the literature). This is several times more than estimated leaching outputs from the rooting zone for the first five years after clearcutting $\left(\sim 1 \mathrm{~kg}^{-1} \mathrm{ha}^{-1} \mathrm{yr}^{-}\right.$ $\left.{ }^{1}\right)$, and equivalent to the three-year estimate in Feller et al. (2000). Furthermore, leaching outputs will likely decrease as new stands become established, even if they do not reach the age of the original old-growth forests, from which an average of $\sim 0.03 \mathrm{~kg}^{-1} \mathrm{ha}^{-1}$ leached over the growing season (1.4 kg ha${ }^{1} \mathrm{yr}^{-1}$ in Feller et al. 2000). However, both atmospheric deposition and $\mathrm{N}$ fixation would have taken place even if forests were not harvested, so caution must be used when considering whether additions from these sources would compensate for increased leaching losses after harvesting using a simple $\mathrm{N}$ budget rather than a process-based model (e.g., Kimmins et al. 1999). The second main output is $\mathrm{N}$ in harvested logs, which was estimated to be $\sim 250 \mathrm{~kg} \mathrm{ha}^{-1}$ in a 400 -year-old stand in the Coastal Western Hemlock zone (Kimmins et al. 2002) and could hence be a much greater source of $\mathrm{N}$ loss than leaching at MASS, especially over the short-term. Similarly, site nutrient losses in a Douglas-fir forest in the Pacific Northwest were attributed to direct removal of nutrients in harvested products rather than to post-harvest leaching or erosion losses (Cole 1995).

Nitrogen losses from the rooting zone in leaching and harvested logs can also be placed in context by comparing leaching losses with $\mathrm{N}$ reserves in the soil (i.e., soil $\mathrm{N}$ capital). At MASS, the soil $\mathrm{N}$ capital (to $30 \mathrm{~cm}$ depth in mineral soil) that presumably has accumulated since the end of glaciation $(\sim 10$ 000 years ago) is estimated to be $\sim 11400 \mathrm{~kg} \mathrm{ha}^{-1}$ (Senyk et al. 1995, Maynard and Senyk 2004). Past catastrophic events that would have led to the natural loss of forests would have also caused some leaching losses, and any fires (rare in this ecosystem) would have volatilized some N. Even with natural $\mathrm{N}$ losses over the past 10000 years, the net $\mathrm{N}$ accretion rate in the soil is therefore about $1 \mathrm{~kg} \mathrm{ha}^{-1} \mathrm{yr}^{-1}$ when estimated over millennia from present soil capital. This is within the same order of magnitude as the difference between annual inputs and outputs estimated above $\left(\sim 3 \mathrm{~kg} \mathrm{ha}^{-1} \mathrm{yr}^{-1}\right.$; Table 3$)$, and is not affected by taking into account transportation of $\mathrm{N}$ from the site in harvested old-growth logs. However, extrapolating impacts of harvesting second-growth stands with much shorter rotations on nutrient cycling at the MASS site will require a greater understanding of $\mathrm{N}$ processes in what will become even-aged, transitional montane stands on present clearcut treatments, and uneven-aged stands on present shelterwood treatments.

Will the $\mathrm{N}$ losses measured at MASS ultimately affect site productivity? Would using shelterwood harvesting instead of clearcutting reduce $\mathrm{N}$ losses? The small amount of $\mathrm{N}$ removed in logs and the minimal leaching from the rooting zone after harvesting in comparison to site capital suggest that clearcut harvesting will not have a major impact on site productivity, at least in the near future. Furthermore, the general lack of statistical differences between the shelterwood and clearcut treatments for key $\mathrm{N}$ processes at MASS suggest that while there may be valid reasons for choosing alternative sil- vicultural systems instead of clearcutting for wildlife, biodiversity, visual aesthetics and other values, it is difficult to make a case for shelterwood harvesting on these sites based on concerns for future site productivity alone.

\section{Conclusions}

Overall, short-term $\mathrm{N}$ cycling processes at MASS remained relatively unaffected by harvesting. Increases in $\mathrm{N}$ mineralization and leaching from the rooting zone after harvesting were relatively small. A large proportion of the mineral $\mathrm{N}$ was ammonium, and the small amounts of nitrate found were not derived through autotrophic conversion of this ammonium, but resulted mainly from heterotrophic decomposition. Nitrogen fluxes from the site were small compared to inputs and, in light of large soil reserves, present harvesting of oldgrowth is unlikely to lead to long-term reductions in site productivity. Nitrogen concentrations in conifer foliage were slightly elevated for two to four years after harvesting, and then decreased. There was therefore little evidence of changes in $\mathrm{N}$ cycling within the first five years that might lead to the sometimes-observed growth check in conifer seedlings on clearcuts in montane coastal forests. However, further monitoring is required to determine if this check will develop by 12 to 15 years after harvesting. Shelterwood harvesting can be used to mitigate effects of clearcutting on some $\mathrm{N}$ processes, but shade may then limit subsequent seedling performance. The trends and consistency in $\mathrm{N}$ cycling processes suggests that the results have application to similar montane forests in the Pacific Northwest. However, the extrapolation of results must be tempered because of the restricted randomization of treatments at MASS resulting from the use of one clearcut and one old-growth stand.

\section{Acknowledgements}

The authors thank the many people who have assisted and collaborated in work at the MASS trial through treatment installation, site maintenance and data collection and analysis. Assistance from C.U. Ro of Environment Canada, Meteorological Service of Canada, in obtaining estimates of atmospheric inputs of $\mathrm{N}$ to the MASS site over the study period is gratefully acknowledged. The majority of the work was funded by Forest Renewal British Columbia (FRBC), MacMillan Bloedel, Weyerhaeuser, Natural Resources Canada (Pacific Forestry Centre) and the University of British Columbia. The authors also thank two anonymous reviewers, an Associate Editor and the Research Editor of The Forestry Chronicle for their many helpful and constructive comments.

\section{References}

Arnott, J.T. and W.J. Beese. 1997. Alternatives to clearcutting in BC coastal montane forests. For. Chron. 73: 670-678.

Ballard, T.M. and R.E. Carter. 1986. Evaluating forest stand nutrient status. BC Ministry of Forests, Land Management Report 20.60 p.

Barg, A.M. and R.L. Edmonds. 1999. Influence of partial cutting on site microclimate, soil nitrogen dynamics, and microbial biomass in Douglas-fir stands in western Washington. Can. J. For. Res. 29: 705-713.

Binkley, D. 1984. Does forest removal increase rates of decomposition and nitrogen release? For. Ecol. Manage. 8: 229-233.

Booth, M.S., J.M. Stark and E. Rastetter. 2005. Controls on nitrogen cycling in terrestrial ecosystems: A synthetic analysis of literature data. Ecol. Monogr. 75: 139-157. 
Bradley, R.L., B.D. Titus, K. Hogg, C. Preston, C.E. Prescott and J.P. Kimmins. 2000. Assessing the controls on soil mineral-N cycling rates in managed coastal western hemlock ecosystems of British Columbia. J. Sust. For. 10: 213-219.

Bradley, R.L., B.D. Titus and K. Hogg. 2001. Does shelterwood harvesting have less impact on forest floor nutrient availability and microbial properties than clearcutting? Biol. Fertil. Soils 34: 162-169.

Bradley, R.L., J.P. Kimmins and W.L. Martin. 2002a. Post-clearcutting chronosequence in the B.C. Coastal Western Hemlock zone: II. Tracking the assart flush. J. Sust. For. 14: 23-43.

Bradley, R.L., W.L. Martin and J.P. Kimmins. 2002b. Post-clearcutting chronosequence in the B.C. Coastal Western Hemlock zone: IV. Modeling forest floor $\mathrm{N}$ dynamics and the possible role of denitrification. J. Sust. For. 14: 69-91.

Chang, S.X. and J.A. Trofymow. 1996. Microbial respiration and biomass (substrate-induced respiration) in soils of old-growth and regenerating forests on northern Vancouver Island, British Columbia. Biol. Fertil. Soils 23: 145-152.

Cole, D.W. 1995. Soil nutrient supply in natural and managed forests. Plant Soil 168-169: 43-53.

Cushon, G.H. and M.C. Feller. 1989. Asymbiotic nitrogen fixation and denitrification in a mature forest in coastal British Columbia. Can. J. For. Res. 19: 1194-1200.

D'Elia, C.F., P.A. Stendler and N. Corwin. 1977. Determination of total nitrogen in aqueous samples using persulphate digestion. Limno. Oceanog. 22: 760-764.

De Boer, W. and G.A. Kowalchuck. 2001. Nitrification in acid soils: micro-organisms and mechanisms. Soil. Biol. Biochem. 33: 853-866. Dunsworth, B.G. and J.T. Arnott. 1995. Growth limitations of regenerating montane conifers in field environments. In J.T. Arnott, W.J. Beese, A.K. Mitchell and J. Peterson (eds.). Montane Alternative Silvicultural Systems (MASS). Proceedings of a Workshop held June 7-8, 1995 in Courtenay, British Columbia. Canada - British Columbia Partnership on Forest Resource Development. pp. 48-68. FRDA Report 238.

Feller, M.C. 1997. Influence of forest harvesting on the nutrient status of ESSFwc2 ecosystems. In C. Hollstedt and A. Vyse (eds.). Sicamous Creek Silvicultural Systems Project: Workshop Proc. BC Min. For. Working Pap. 24/1997. pp. 121-133.

Feller, M.C. and J.P. Kimmins. 1984. Effects of clearcutting and slash burning on streamwater chemistry and watershed nutrient budgets in southwestern British Columbia. Water Resour. Res. 20: 29-40.

Feller, M.C. and P. Olanski. 1995. Influence of alternative timber harvesting regimes in montane coastal western hemlock zone forests on soil nutrient leaching: initial results. In J.T. Arnott, W.J. Beese, A.K. Mitchell and J. Peterson (eds.). Montane Alternative Silvicultural Systems (MASS). Proceedings of a Workshop held June 7-8, 1995 in Courtenay, British Columbia. Canada - British Columbia Partnership on Forest Resource Development. pp. 89-100. FRDA Report 238.

Feller, M.C., R. Lehmann and P. Olanski. 2000. Influence of forest harvesting intensity on nutrient leaching through soil in southwestern British Columbia. J. Sust. For. 10: 241-247.

Grenon, F. R.L. Bradley, G. Joanisse, B.D. Titus and C.E. Prescott. 2004. Mineral N availability for conifer growth following clearcutting: responsive versus non-responsive ecosystems. For. Ecol. Manage. 188: 305-316.

Halpern, C.B. 1988. Early successional pathways and the resistance and resilience of forest communities. Ecology 69: 1703-1715.

Hart, S.C., G.E. Nason, D.D. Myrold and D.A. Perry. 1994. Dynamics of gross nitrogen transformations in an old-growth forest: the carbon connection. Ecology 75: 880-891.

Hawkins, B.J. and J.A. Moran. 2003. Growth response of Abies amabilis advance regeneration to overstory removal, nitrogen fertilization and release from Vaccinium competition. For. Sci. 49: 799-806.
Hawkins, B.J., R.S. Koppenaal and A.K. Mitchell. 2002. Proximity to a stand edge influences growth of advance and planted Pacific silver fir seedlings. Northwest Science 76: 221-229.

Heath, B., P. Sollins, D.A. Perry and K. Cromack, Jr. 1988. Asymbiotic nitrogen fixation in litter from Pacific Northwest forests. Can. J. For. Res. 18: 68-74.

Hughes, J.W., T.J. Fahey and B. Browne. 1987. A better seed and litter trap. Can. J. For. Res. 17:1623-1624.

Jewett, K., D. Daugharty, H.H. Krause and P.A. Arp. 1995. Watershed responses to clear-cutting: effects on soil solutions and stream discharge in central New Brunswick. Can. J. Soil Sci. 75: 475-490.

Keenan, R.J. and J.P. Kimmins. 1993. The ecological effects of clearcutting. Environ. Rev. 1: 121-144.

Keenan, R.J., C.E. Prescott and J.P. Kimmins. 1995. Litter production and nutrient resorption in western red cedar and western hemlock forests on northern Vancouver Island. Can. J. For. Res. 25: 1850-1857.

Kimmins, J.P., D. Binkley, L. Chatarpaul and J. de Catanzaro. 1985. Biogeochemistry of temperate forest ecosystems: literature on inventories and dynamics of biomass and nutrients. Can. For. Serv., Inf. Rep. PI-X-47E/F.

Kimmins, J.P., D. Mailly and B. Seely. 1999. Modelling forest ecosystem net primary production: the hybrid simulation approach used in FORECAST. Ecological Modelling 122: 195-224.

Kimmins, J.P., W.L. Martin and R.L. Bradley. 2002. Post-clearcutting chronosequence in the B.C. Coastal Western Hemlock zone: III. Sinks for mineralised or dissolved organic N. J. Sust. For. 14: 45-68. Kirkham, D. and W.V. Bartholemew. 1954. Equations for following nutrient transformation in soil, utilizing tracer data. Soil Sci. Soc. Am. J. 18: 33-34.

Koppenaal, R.S. and B.J. Hawkins. 2000. Release of advance regeneration under varying overstory retention in a coastal montane forest. FRBC Year End Report 1999/2000, FA96568-RE.

Koppenaal, R.S. and A.K. Mitchell. 1992. Regeneration of montane forests in the coastal Western Hemlock zone of British Columbia: A literature review. BC Ministry of Forests - Forestry Canada, FRDA Report 192. 22 p.

Krause, H.H. 1982. Nitrate formation and movement before and after clear-cutting of a monitored watershed in central New Brunswick, Canada. Can. J. For. Res. 12: 922-930.

Larsen, M.J., M.F. Jurgensen and A.E. Harvey. 1982. $\mathrm{N}_{2}$ fixation in brown-rotted soil wood in an intermountain cedar-hemlock ecosystem. For. Sci. 28: 292-296.

Martin, C.W. and R.D. Harr. 1989. Logging of mature Douglas-fir in western Oregon has little effect on nutrient output budgets. Can. J. For. Res. 19: 35-43.

Martin, W.L., R.L. Bradley and J.P. Kimmins. 2002. Post-clearcutting chronosequence in the B.C. Coastal Western Hemlock zone: I. Changes in forest floor mass and N storage. J. Sust. For. 14: 1-22.

Maynard, D.G. and J.P. Senyk. 2004. Soil disturbance and five-year tree growth in a montane alternative silvicultural system (MASS) trial. For. Chron. 80: 573-582.

McColl, J.G. 1977. Retention of soil water following forest cutting. Soil Sci. Soc. Am. J. 41: 984-988.

Mitchell, A.K. 2001. Growth limitations for conifer regeneration under alternative silvicultural systems in a coastal montane forest in British Columbia, Canada. For. Ecol. Manage. 145: 129-136.

Mitchell, A.K. and J.T. Arnott. 1995. Montane Alternative Silvicultural Systems: ecophysiology of regenerating conifers. In J.T. Arnott, W.J. Beese, A.K. Mitchell and J. Peterson (eds.). Montane Alternative Silvicultural Systems (MASS). Proceedings of a Workshop held June 7-8, 1995 in Courtenay, British Columbia. Canada - British Columbia Partnership on Forest Resource Development. pp. 69-80. FRDA Report 238. 
Mitchell, A.K., B.G. Dunsworth, T. Bown and J.A. Moran. 2003. Above-ground biomass predicts growth limitation in amabilis fir and western hemlock seedlings. For. Chron. 79: 285-290.

Mitchell, A.K., B.G. Dunsworth, J.T. Arnott, R. Koppenaal, R. Benton, G. Goodmanson, T. Bown and J. Sandford. 2004. Growth limitations of planted conifers regenerating under Montane Alternative Silvicultural Systems (MASS): Seven-year results. For. Chron. 80: 241-250.

Mitchell, S.J. and W.J. Beese. 2002. The retention system: reconciling variable retention with the principles of silvicultural systems. For. Chron. 78: 397-403.

Powers, R.L. 1983. Forest research fertilization in California. In R. Ballard and S.P. Gessel (eds.). IUFRO symposium on forest site and continuous productivity. pp. 388-397. USDA For. Serv., Gen. Tech. Rep. PNW-163.

Prescott, C.E. 1995. Rates of organic matter decomposition and nitrogen mineralization in forest floors at MASS. In J.T. Arnott, W.J. Beese, A.K. Mitchell and J. Peterson (eds.). Montane Alternative Silvicultural Systems (MASS). Proceedings of a Workshop held June 7-8, 1995 in Courtenay, British Columbia. Canada - British Columbia Partnership on Forest Resource Development. pp. 81-88. FRDA Report 238.

Prescott, C.E. 1997. Effects of clearcutting and alternative silvicultural systems on rates of decomposition and nitrogen mineralization in a coastal montane coniferous forest. For. Ecol. Manage. 95: 253-260.

Ro, C.U. 2002. Canadian National Atmospheric Chemistry Database (NAtChem/Precipitation). Environment Canada, Meteorological Service of Canada, 4905 Dufferin Street, Toronto, Ontario, Canada, $\mathrm{M} 3 \mathrm{H}$ 5T4.

Romell, L.-G. 1957. Man-made "nature" of northern lands. In Proc. and Papers of the Sixth Techn. Meeting Int. Union for Conservation of Nature and Natural Resources, Edinburgh, June 1956. pp. 51-53. Soc. for the Promotion of Nature Reserves, London.

Rosén, K., J.-A. Aronson and H.M. Eriksson. 1996. Effects of clearcutting on streamwater quality in forest catchments in central Sweden. For. Ecol. Manage. 83: 237-244.

Schimel, J.P. and J. Bennett. 2004. Nitrogen mineralization: Challenges of a changing paradigm. Ecology 85: 591-602.

Seely, B., P.A. Arp, and J.P. Kimmins. 1997. A forest hydrology submodel for simulating the effect of management and climate change on stand water stress. In A. Amaro and M. Tome (eds.). Empirical and process-based models for forest, tree and stand growth simulation, 21-27 September 1997, Oerias, Portugal (Edicoes Salamandra, Lisboa). pp. 463-477.

Senyk, J., D. Craigdallie and E. Wass. 1995. Effects of harvesting and trail rehabilitation on soil and long-term forest productivity in alternate silviculture systems trial. In J.T. Arnott, W.J. Beese, A.K. Mitchell and J. Peterson (eds.). Montane Alternative Silvicultural Systems (MASS). Proceedings of a Workshop held June 7-8, 1995 in
Courtenay, British Columbia. Canada - British Columbia Partnership on Forest Resource Development. pp. 25-36. FRDA Report 238.

Siira-Pietikäinen, A., J. Pietikäinen, H. Fritze and J. Haimi. 2001. Short-term responses of soil decomposer communities to forest management: clear felling versus alternative forest harvesting methods. Can. J. For. Res. 31: 88-99.

Silvester, W.B., P. Sollins, T. Verhoeven and S.P. Cline. 1982. Nitrogen fixation and acetylene reduction in decaying conifer boles: effects of incubation time, aeration, and moisture content. Can. J. For. Res. 12: 646-652.

Sollins, P, S.P. Cline, T. Verhoeven, D. Sachs and G. Spycher. 1987. Patterns of log decay in old-growth Douglas-fir forests. Can. J. For. Res. 17: 1585-1595.

Stark, N.M. 1979. Nutrient losses from timber harvesting in a larch/Douglas-fir forest. USDA For. Serv., Research Paper INT-231. $41 \mathrm{p}$.

Stark, J.M. and S.C. Hart. 1997. High rates of nitrification and nitrate turnover in undisturbed coniferous forests. Nature 385: 61-64.

Swank, W.T., J.M. Vose and K.J. Elliott. 2001. Long-term hydrologic and water quality responses following commercial clearcutting of mixed hardwoods on a southern Appalachian catchment. For. Ecol. Manage. 143: 163-178.

Tarrant, R.F., L.A. Issac and R.F. Chandler. 1951. Observations on litterfall and foliage content of some Pacific Northwest tree species. J. For. 49: 914-915.

Titus, B.D., B.A. Roberts and K.W. Deering. 1998. Nutrient removals with harvesting and by deep percolation from white birch (Betula papyrifera [Marsh.]) sites in central Newfoundland. Can. J. Soil Sci. 78: 127-137.

Vitousek, P.M. 1981. Clear-cutting and the nitrogen cycle. In F.E. Clark and T. Rosswall (eds.). Terrestrial Nitrogen Cycles. Ecol. Bull. (Stockholm) 33: 631-642.

Vitousek, P.M. 1983. The effects of deforestation on air, soil and water. In B. Bolin and R.B. Cook (eds.). The Major Biogeochemical Cycles and Their Interactions. Scientific Committee on Problems of the Environment (SCOPE). J. Wiley, New York. SCOPE 21: 223-245. Vitousek, P.M. and J.M. Melillo. 1979. Nitrate losses from disturbed forests: patterns and mechanisms. Forest Sci. 25: 605-619.

Vitousek, P.M. and W.A. Reiners. 1975. Ecosystem succession and nutrient retention: a hypothesis. BioScience 25: 376-381.

Vitousek, P.M., J.D. Aber, R.W. Howarth, G.E. Likens, P.A. Matson, D.W. Schindler, W.H. Schlesinger and D.G. Tilman. 1997. Human alteration of the global nitrogen cycle: sources and consequences. Ecol. Appl. 7: 737-750.

Whitford. W.G., V. Meentemeyer, T.R. Seastedt, K. Cromack, D. Crossley, P. Santos, R. L. Todd and J.B. Waide. 1981. Exceptions to the AET model: deserts and clearcut forests. Ecology 62: 275-277. 